\title{
The Pyhäntaka formation, southern Finland: a sequence of metasandstones and metavolcanic rocks upon an intra-orogenic unconformity
}

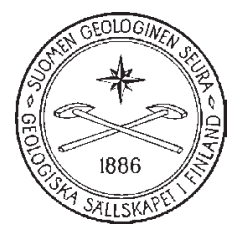

\author{
Mikko NiRonen \\ Geological Survey of Finland, P.O. Box 96, 02151 Espoo, Finland
}

\begin{abstract}
Detrital zircon studies suggest that the few quartzite occurrences in southern Finland are younger than $1.87 \mathrm{Ga}$ and express sedimentation after 1.89-1.87 Ga accretional deformation and metamorphism in the Svecofennian orogenic belt. Detailed field work in the high-grade metamorphic Pyhäntaka area allowed to distinguish an overturned formation within metagraywackes (cordierite paragneisses) and psammites. The Pyhäntaka formation has a maximum thickness of 1000 meters and consists of quartzite overlain by meta-arkose, metatuff, and metabasalt on top. An uncorformity, expressed by a weathering surface, separates the quartzite from underlying metagraywacke. The metavolcanic rocks within, stratigraphically underlying and overlying the Pyhäntaka formation are mostly basalts and basaltic andesites, but a felsic volcanic rock and dacitic fragments in volcaniclastic rocks imply bimodal affinity. The quartzite was deposited during a stable intra-orogenic period probably after accretion but before 1.83-1.80 Ga collisional deformation and metamorphism in the Svecofennian orogen. Rifting during the intraorogenic period and accumulation of variable material in the rift from nearby sources by fluvial processes is a viable scenario for deposition and preservation of the Pyhäntaka formation. Geochemical diagrams of the metavolcanic rocks show a scatter that is best explained by source heterogeneity and crustal contamination. Despite their (likely) postaccretion setting the basaltic rocks show arc-type characteristics due to subductionmodified lithospheric mantle sources. Because of recycling, also the paragneisses in the Pyhäntaka area are geochemically similar in spite that they represent different tectonic settings. The use of elemental geochemistry alone appears to be insufficient for discriminating tectonic settings of basalts or graywackes in the Svecofennian of southern Finland where accretion and post-accretion settings were largely obliterated by late collision.
\end{abstract}

Key words: quartzites, metasandstone, metavolcanic rocks, geochemistry, Paleoproterozoic, Svecofennian orogeny.

Corresponding author email: mikko.nironen@gtk.fi

Editorial handling: Arto Luttinen 


\section{Introduction}

The Paleoproterozoic crust of southern Finland may be divided into two terranes (Fig. 1, inset). In the evolutionary model of Lahtinen et al. (2005) the Svecofennian orogeny (a term that covers several orogenic episodes) initiated by accretion of an arc complex, including a microplate, to the Archean continent $1.91 \mathrm{Ga}$ ago (Lapland-Savo orogeny). This accreted arc complex is the Central Svecofennian terrane. Accretion of another arc complex (Fennian orogeny) started $\sim 1.89 \mathrm{Ga}$ ago, leading to deformation and voluminous magmatism in the Central Svecofennian terrane, as well as metamorphism that attained peak at $\sim 1.88 \mathrm{Ga}$ (Mouri et al., 1999; Lahtinen et al., 2009). By 1.87 Ga, deformation had almost ceased in the Central Svecofennian terrane, while plutonism continued in the newly

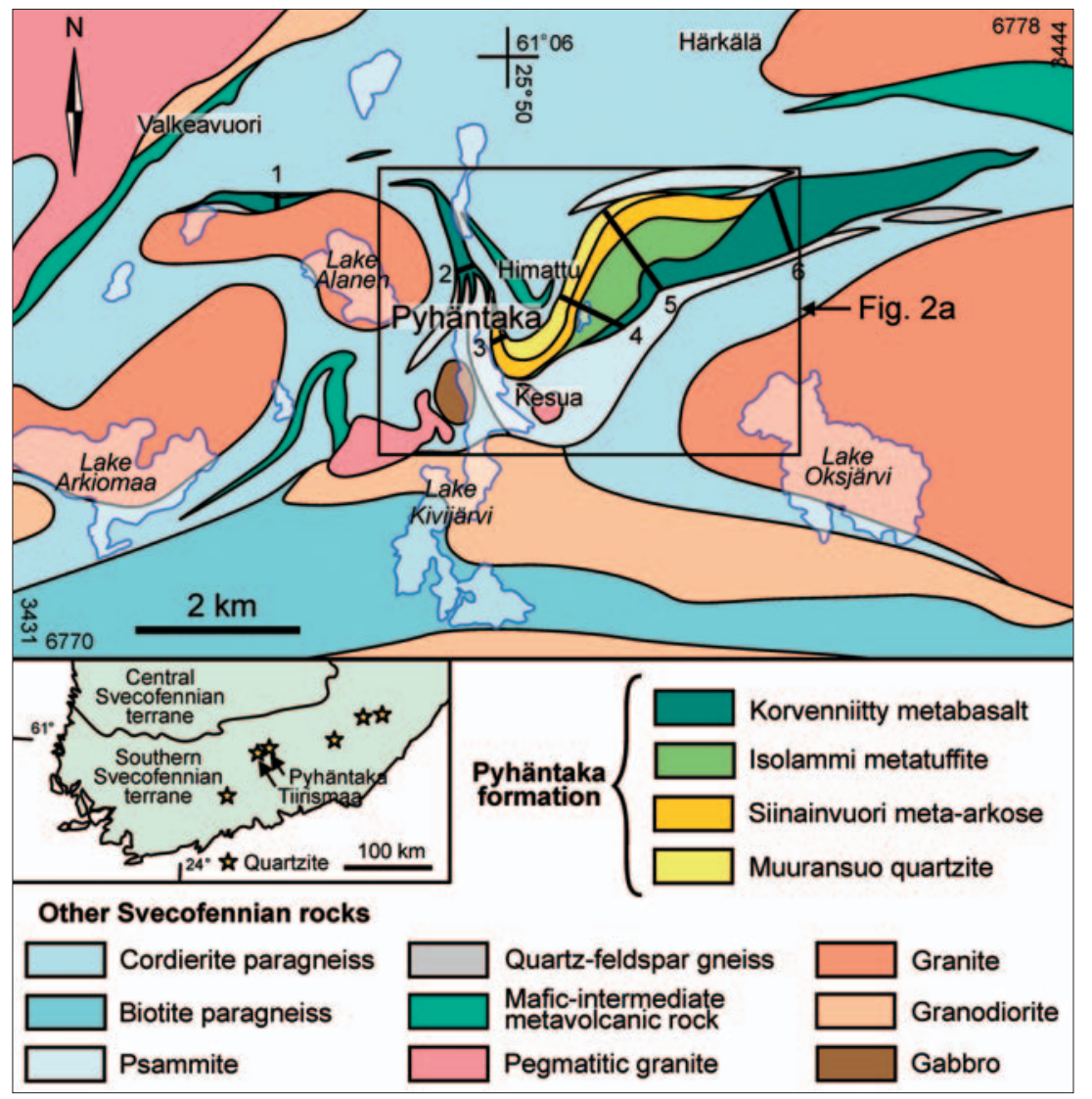

Fig. 1. Bedrock map of the Pyhäntaka area (modified from Lehijärvi, 1970). The inset shows the position of the Pyhäntaka area in southern Finland. Lines with numbers denote stratigraphic columns in Fig. 4. accreted arc complex (Southern Svecofennian terrane) until $1.80 \mathrm{Ga}$. According to the model, orogenic collapse led to crustal-scale extension at 1.86$1.84 \mathrm{Ga}$ in the Southern Svecofennian terrane. Subsequent continental collision (Svecobaltic orogeny) at 1.84-1.80 Ga caused transpressional deformation and a younger peak of metamorphism between $1.83 \mathrm{Ga}$ and 1.81 Ga (Ehlers et al., 1993; Väisänen et al., 2002; Mouri et al., 2005). A complex sequence of deformation, high grade metamorphism and associated granitic plutonism largely obliterated primary structures in the supracrustal rocks of the Southern Svecofennian terrane.

There are a few small metasandstone (mostly quartzite) occurrences in southern Finland, and all of them are within the Southern Svecofennian terrane. The geology of the Tiirismaa quartzite (Fig 1, inset) has been studied in some detail (Eskola \& Nieminen, 1938; Lehijärvi, 1964). About $15 \mathrm{~km}$ ENE of the Tiirismaa quartzite, there is another small quartzite body called Pyhäntaka quartzite within cordierite paragneiss. Age data for detrital zircons in the Tiirismaa and Pyhäntaka quartzites (Lahtinen et al., 2002; Bergman et al., 2008) are compatible with a maximum deposition age of $1.87-$ $1.86 \mathrm{Ga}$ for the quartzites.

The aim of this study is to define a new lithostratigraphic formation in a highgrade metamorphic area by presenting the rock types, stratigraphy, and general structure around the quartzite at Pyhäntaka. Moreover, the geochemical characteristics of the metavolcanic and metasedimentary rocks at Pyhäntaka as well as a depositional model to explain the preservation of the formation are presented. 


\section{Supracrustal rocks}

The rocks in the Pyhäntaka area (Fig. 1) were metamorphosed at upper amphibolite facies conditions and most of the primary structures were transposed or obliterated during deformation and metamorphism. However, detailed field work allowed to define a lithostratigraphic formation within lithodemic units, here named as the Pyhäntaka formation.

\subsection{Rocks north of the Pyhäntaka formation}

The rock sequence to the north of the Pyhäntaka formation consists of cordierite paragneiss with few intercalations of mafic-intermediate metavolcanic rock, and a fine-grained psammite unit with a maximum thickness of $250 \mathrm{~m}$ (Fig. 2). The thickness of the paragneiss is unknown; folding has caused repetition of strata.

The cordierite paragneiss is a migmatitic metagraywacke, probably of turbiditic origin, with alternating pelitic and (generally thicker) psammitic layers $1-20 \mathrm{~cm}$ in width. K-feldspar and cordierite porphyroblasts are abundant in the pelitic layers, and variable amounts of small leucosome veins in pelitic layers are expressions of in situ melting.

Metavolcanic rocks occur as rather thin lenses within the paragneiss. These lenses probably represent primary interlayers that have been attenuated and broken during deformation. The mafic metavolcanic rock in the core of the fold structure, at Himattu (Fig. 1), is volcaniclastic with abundant elongate, mafic to felsic clasts (Fig. 3a). The fine-grained clasts contain the same main minerals as the matrix (plagioclase, hornblende and quartz). The contact between the metavolcanic rock and gneiss is gradational within a few tens of centimetres. In the northwestern part of the study area, at Valkeavuori (Fig. 1), the most common rock type is a mafic-intermediate rock with primary compositional layering. Small hornblende (uralite) phenocrysts are typical in the mafic varieties whereas the intermediate variety contains biotite in excess of hornblende. A mafic metavolcanic rock extending from the Härkälä area further east varies from a homogeneous type to porphyritic type, which is in places plagioclase-phyric and in other places uralitephyric. The thickness of this unit is poorly constrained.

\subsection{Pyhäntaka formation}

The Pyhäntaka formation is here divided into four members: Muuransuo quartzite, Siinainvuori metaarkose, Isolammi metatuffite, and Korvenniitty metabasalt (Fig. 1). The stratigraphic sequence is based on detailed mapping at unit boundaries and two cross-bedding observations found in the quartzite and meta-arkose. Stratigraphic columns across the Pyhäntaka formation are shown in Fig. 4. The maximum thickness of the formation is about 1000 meters.

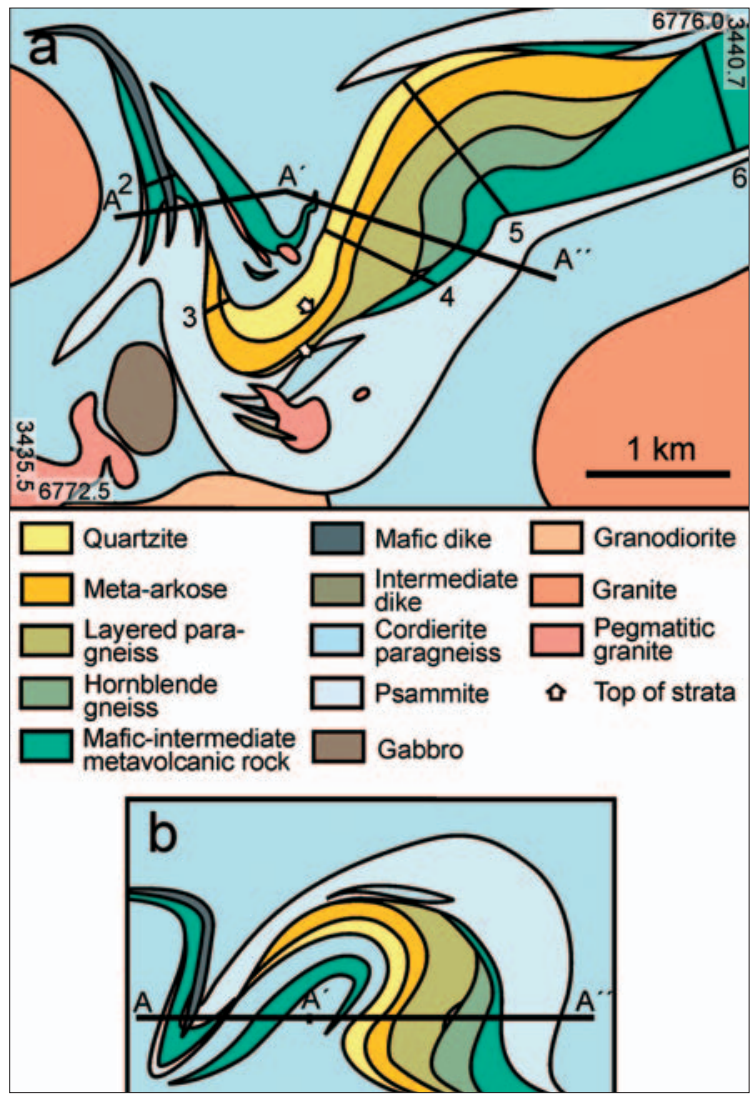

Fig. 2. (a) Close-up of the lithology in the Pyhäntaka area. (b) Cross-section of the Pyhäntaka formation along the line $A-A^{-}-A^{-\prime}$ in Fig. 2a. Lines with numbers denote stratigraphic columns in Fig. 4. 


\subsubsection{Muuransuo quartzite}

The Muuransuo quartzite, previously called Pyhäntaka quartzite (Bergman et al., 2008), occurs as a curved body with a length of $4 \mathrm{~km}$ and maximum thickness of $150 \mathrm{~m}$. A thin extension of the quartzite was found $3.5 \mathrm{~km}$ westward (north of the Alanen granite; Fig. 1). At Himattu, cordierite gneiss grades first to K-feldspar-sillimanite gneiss and then to sillimanite and magnetite -bearing quartz-rich rock and shows increasing strain within 20 meters towards the quartzite. This indicates a remarkable compositional change in the gneiss towards the overlying quartzite. Although the actual contact to the quartzite is covered by soil, the uppermost part of the paragneiss is interpreted as a weathering surface that has been sheared during tectonic movements (Lahtinen and Nironen, 2010).

The Muuransuo quartzite contains 70-97 \% quartz (Lehijärvi, 1979; Bergman et al., 2008). Sillimanite knots and a reddish tint due to hematite pigment characterize the rock. Elongate quartz grains without crystallographic preferred orientation are typical of samples from foliated rock whereas undulose extinction and $120^{\circ}$ triple junctions are common in samples showing less strain. Sillimanite (2-20\%) occurs as both fibrous and rhombshaped crystals between and within the quartz grains. Feldspar, opaque minerals (mainly magnetite), secondary muscovite, apatite, zircon and tourmaline are found as accessory minerals. Although metamorphism and deformation have mostly obliterated clastic texture and primary structures, crossbedding with sets of $20-40 \mathrm{~cm}$ thickness is visible in places as magnetite-rich stripes (Fig. 3b). Crossbedding indicates stratigraphic younging towards southeast. Darkish angular or rounded fragments, $1-5 \mathrm{~cm}$ up to $10 \mathrm{~cm}$ in size and consisting of sillimanite (partly altered to biotite and muscovite), magnetite, ilmenite and fine-grained quartz, occur at the site where cross-bedding is visible, especially in zones parallel to bottom set (Fig. 3c). The fragments are interpreted as clasts from hardened upper part of weathered crust (lateritic duricrust; Lahtinen \& Nironen, 2010).

\subsubsection{Siinainvuori meta-arkose}

The meta-arkose on top of the quartzite has a maximum thickness of $170 \mathrm{~m}$. The boundary between quartzite and meta-arkose is gradational and the meta-arkose contains thin quartzite interlayers. The meta-arkose is a reddish rock that typically contains white sillimanite knots on weathered surface. The main mineral is quartz, varying in content from $40 \%$ to $70 \%$. The amount of K-feldspar varies from $10 \%$ to $50 \%$ (Lehijärvi, 1979). K-feldspar may occur as tiny grains in the interstices of larger quartz grains or as grains equal in size to quartz (Fig. 3d). Plagioclase also occurs as tiny grains in the interstices of quartz grains; the tiny feldspars appear to be primary grains that were rounded during transportation. Fibrolitic sillimanite is a typical minor mineral. Biotite, opaque minerals, zircon/monazite, apatite and tourmaline are other accessory minerals. Towards southeast (top), darker interlayers of volcanic material (ampihibole, quartz and plagioclase-rich rock fragments) appear in the meta-arkose.

\subsubsection{Isolammi metatuffite}

The gneiss above the Siinainvuori meta-arkose has a maximum thickness of 500 meters. The lower part consists of layered cordierite gneiss with abundant reddish veins rich in K-feldspar as well as hornblende-bearing clasts (Fig. 3e). Almost total pinitization of cordierite and the K-feldspar-rich veins suggest partial melting or strong fluid activity. The cordierite gneiss grades upwards into hornblendequartz-feldspar gneiss and fine-grained, finely layered biotite-hornblende schist. The unit is probably of mixed volcanic-sedimentary origin grading upwards from sedimentary-dominated to volcanicdominated.

\subsubsection{Korvenniitty metabasalt}

The Isolammi metatuff grades within one meter into the Korvenniitty metabasalt. The most common type of the metabasalt is a fragmental volcaniclastic rock, containing ovoidal, flattened clasts $3-15 \mathrm{~cm}$ 

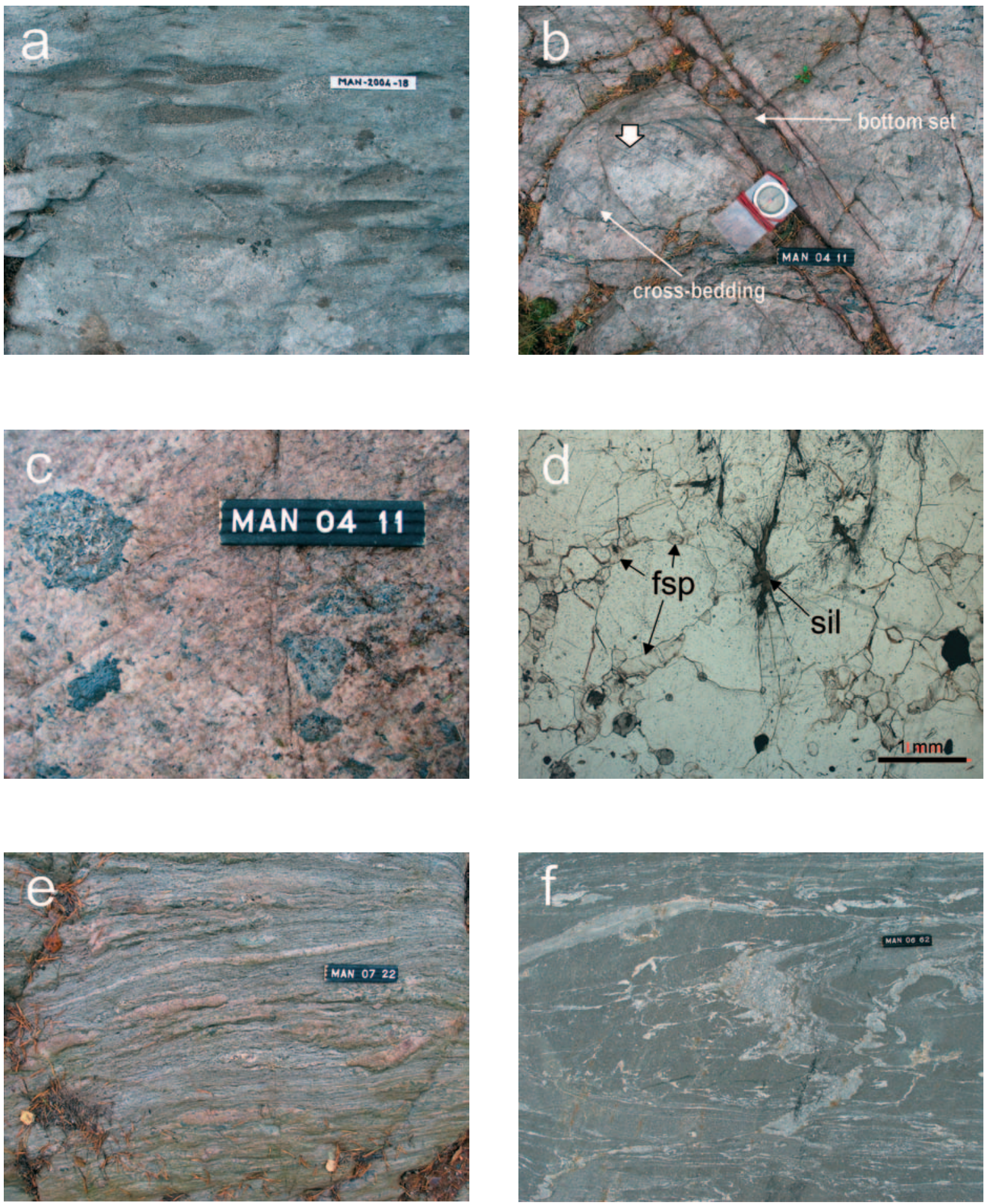

Fig. 3. Photographs of the rock types in the Pyhäntaka area. (a) Volcaniclastic rock with flattened clasts. Length of code $12 \mathrm{~cm}$. (b) Muuransuo quartzite with faint cross-bedding and dark fragments. Length of code bar $12 \mathrm{~cm}$. (c) Close-up of dark fragments in Muuransuo quartzite, consisting of sillimanite, biotite, muscovite, magnetite, ilmenite and quartz. (d) Photomicrograph of Siinainvuori meta-arkose. K-feldspar and plagioclase (fsp) grains occur in the interstices of larger quartz grains. Fibrolithic sillimanite (sil) occurs as aggregates. (e) Migmatitic Isolammi metatuffite, with K-feldspar-rich veins in cordierite gneiss. (f) Kivijärvi granodiorite, with two sheared and intermingled rock types and leucosome veins. 
up to $50 \mathrm{~cm}$ in length. Thus the metavolcanic rock is similar to the metavolcanic interlayers in the paragneiss underlying the Pyhäntaka formation. The matrix is composed (in decreasing amount) of plagioclase, hornblende, biotite and quartz with secondary chlorite. The clasts are generally more felsic than the matrix, consisting of plagioclase and quartz, with hornblende or biotite as mafic mineral. The metabasalt may also occur as a lava breccia with epidote-rich veinlets and plagioclase and quartz accumulations in a fine-grained matrix of diopside, hornblende and plagioclase. The basalt occurs also as a layered rock. A homogeneous type with small hornblende (uralite) phenocrysts is interpreted as a sill (Fig. 2)

At the western extension of the Muuransuo quartzite, the small quartzite occurrence grades into metabasalt within $20 \mathrm{~cm}$. The metabasalt is layered at the contact but becomes fragmental within a few tens of meters. It is correlated with the Korvenniitty metabasalt (see column 1 in Fig. 4). Thus the Korvenniitty metabasalt occurs as an east-west oriented body that has been attenuated and broken during deformation (Fig. 1). The total length at

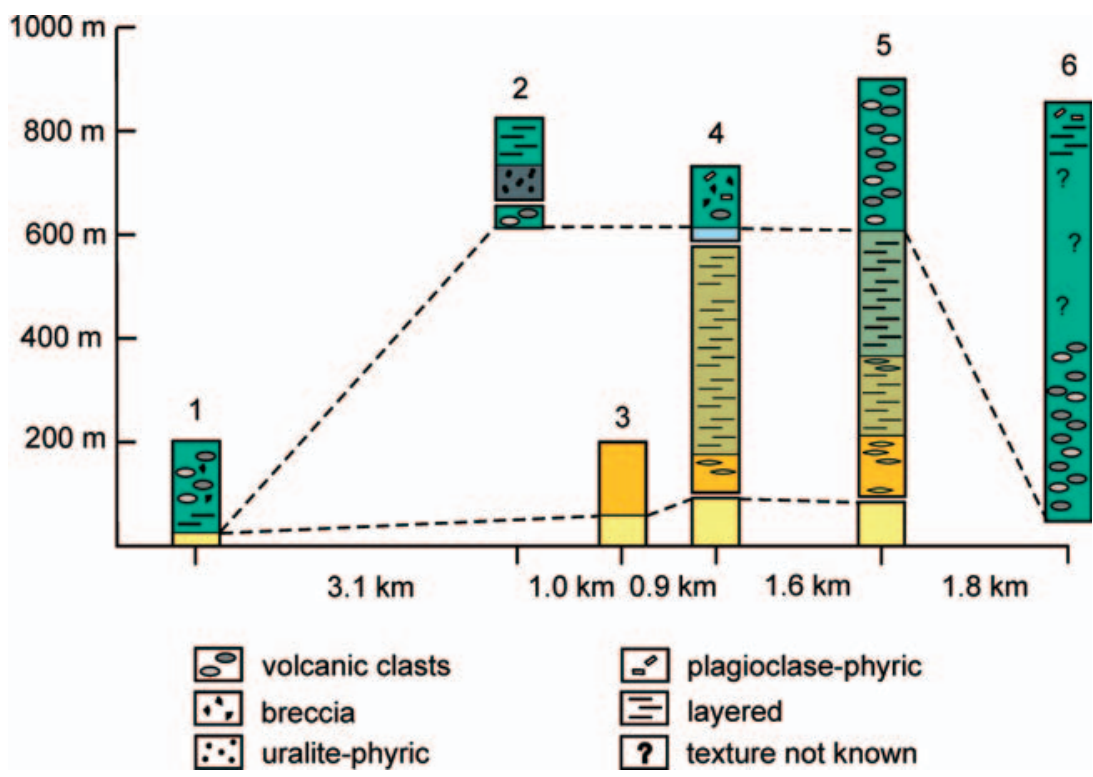

Fig. 4. Generalized stratigraphic columns of the Pyhäntaka formation. Locations for the columns are shown in Figs. 1 and 2. Distances indicate distances between column locations. Marking of lithological units as in Fig. 2. Gaps in columns indicate sites where contact has not been detected. The base level below the quartzite is tectonized contact. present is $13 \mathrm{~km}$ and maximum thickness $800-900$ m (Figs. 2 and 4).

\subsection{Rocks south of the Pyhäntaka formation}

The supracrustal sequence to the south (on top) of the Korvenniitty metabasalt consists of psammite, cordierite paragneiss with a metabasaltic interlayer, and biotite paragneiss (to the south of the Kivijärvi granodiorite). The psammite occurs as interlayers in the paragneiss and occupies a larger, rather homogeneous area at Kesua (Figs. 1 and 2). It is a fine-grained, faintly layered rock with biotite as the only mafic mineral. K-feldspar porphyroblasts are found in places. The rock probably consists of a mixture of volcanic detritus and epiclastic sedimentary material. Similar to cordierite paragneiss north of the Pyhäntaka formation, the cordierite paragneiss is a migmatitic metagraywacke with well-preserved primary layering in fold hinge areas and transposed compositional layering in limb areas. K-feldspar and cordierite porpyroblasts are abundant in pelitic layers. However, neosome veins and crosscutting granitic dikes are less abundant than at Härkälä. The matrix consists of quartz, biotite and plagioclase as well as accessory tourmaline, apatite and zircon. The migmatitic biotite paragneiss contains abundant thin leucocratic veins parallel to foliation but appears to lack porphyroblasts.

Quartz-feldspar gneiss was found in the eastern part of the study area (Fig. 1). The rock is faintly layered, finegrained, and probably of volcanic origin. The metabasalt interlayer in the paragneiss east of Lake Arkiomaa (Fig. 1) occurs as a layered type and a homogeneous type with uralite phenocrysts (2- 
$8 \mathrm{~mm}$ ) in a plagioclase-rich groundmass; the latter was interpreted as a sill.

\section{Plutonic and dike rocks}

Foliated granodiorites in the study area have been considered to be of 1.89-1.87 Ga age (Korsman et al., 1997). An east-west trending plutonic body crossing Lake Kivijärvi (Fig. 1), here named as Kivijärvi granodiorite, is a heterogeneous rock consisting of medium-grained tonalite-granodiorite and intermingled darkish, fine-grained rock type that occasionally contains small feldspar phenocrysts. The granodiorite and the fine-grained rock occur in a variety of mutual associations: in places the granodiorite appears to crosscut the darker rock, in other places the rocks show structures typical of mingled magmas (Fig. 3f). As both rocks are intensely deformed with magmatic foliation, they may express two magmas emplaced coevally in a shear zone.

The Härkälä granite in the northeastern part of the study area is a porphyritic, slightly foliated rock with subhedral to anhedral K-feldspar megacrysts $5-20 \mathrm{~mm}$ in size in a medium-grained granodioriticgranitic matrix.

The granite bodies vary in appearance: the Oksjärvi granite around Lake Oksjärvi is medium-grained and exhibits concentric foliation whereas the Alanen and Arkiomaa granites are fine-grained and almost undeformed (Fig. 2). These granites have been assigned to the 1.84-1.82 Ga granite group (Korsman et al., 1997). The pegmatitic granite in the west as well as the smaller pegmatitic bodies are undeformed and sharply crosscut adjacent rocks.

An ovoidal gabbroic body in the center of the study area, here named as Sopenmäki gabbro, also sharply crosscuts the adjacent gneisses. The rock is homogeneous and medium-grained with subophitic texture, consisting of plagioclase, orthopyroxene, colorless amphibole as an alteration product of pyroxene, and biotite. The magmatic texture, the alteration phenomena and the biotite laths suggest that we see the top of an intrusion that was subject to autometamorphism.

A few crosscutting mafic dikes are found in paragneisses below and above the Pyhäntaka formation. The width of theses dikes varies from $10 \mathrm{~cm}$ to almost 3 meters. A $10 \mathrm{~m}$ wide dike rock of intermediate composition crosscuts K-feldsparcordierite gneiss south of (above) the Pyhäntaka formation and a pegmatitic granite body. The rock contains plagioclase, hornblende, biotite and clinopyroxene as main minerals, and quartz, magnetite and apatite as accessory minerals. The intermediate dike is probably younger than the mafic ones.

\section{General structural pattern}

The structural pattern of the Pyhäntaka area is shown schematically in Fig. 5. A more detailed presentation of the structure is given by Nironen and Mänttäri (2011). The predominant foliation is usu-

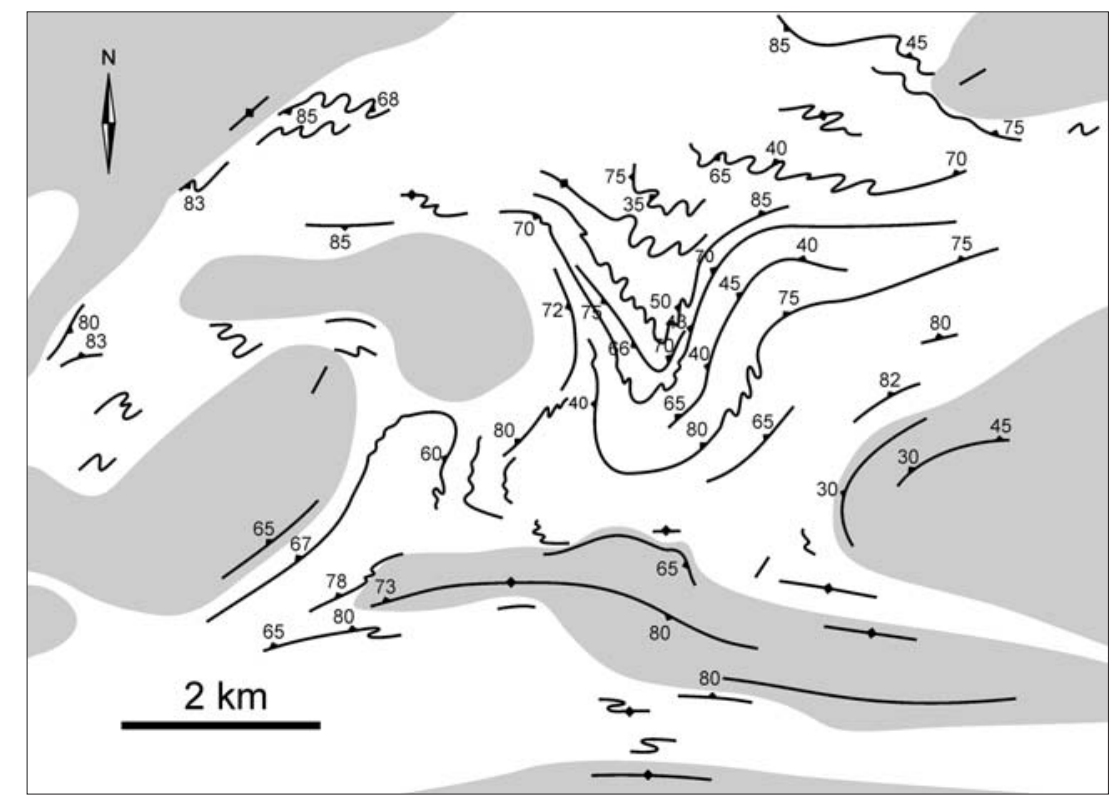

Fig. 5. General structural pattern in the Pyhäntaka area. The predominant foliation is shown as form lines. 
ally subparallel to the lithological layering, dipping moderately to steeply N-NNW in areas not deformed by later folding. Prominent leucosome development is associated with the predominant foliation. The clasts in volcaniclastic rocks are flattened. The two top-of-strata observations indicate that the rocks of the Pyhäntaka formation are overturned to the south.

In the center of the Pyhäntaka area, the predominant foliation has been folded. In the core of the major fold the axial plane, foliation is of crenulation type, with generally steeply dipping axial trace. An intersection lineation is parallel to moderately to gently NE or SW plunging fold axis. The structure is interpreted as an inclined, slightly overturned fold (Fig. 2b).

The Kivijärvi and Oksjärvi plutons exhibit foliation that is conformable with predominant foliation in the adjacent supracrustal rocks whereas the Alanen and Arkiomaa granites are virtually undeformed, suggesting a younger emplacement age for the latter.

The traces of young folding with east-west trending axial trace is found in limb areas of the major fold. Folding is open to tight; no axial plane foliation has developed. Pegmatitic granite bodies in the center of the study area crosscut the younger fold structures.

\section{Geochemistry}

The samples for the geochemical study were analyzed in the Chemical Laboratory, Geological Survey of Finland (Table 1). Major elements and $\mathrm{Ba}, \mathrm{Rb}$, $\mathrm{Sr}, \mathrm{Y}, \mathrm{V}, \mathrm{Cu}, \mathrm{Zn}, \mathrm{Cr}$ and $\mathrm{Ni}$ were determined with XRF, and the other elements with ICP-MS. More detailed description of the analytical methods, precision and lowest reliable concentration is given in Rasilainen et al. (2007).

The metavolcanic rocks in the Pyhäntaka area are divided into five groups according to their location: Pyhäntaka NW, Pyhäntaka NE, Pyhäntaka C (Center), Pyhäntaka fm (metavolcanic rocks of the Pyhäntaka formation), and Pyhäntaka SW (Fig. 6, Table 1). A sample from mafic dike at Härkälä (sample 115/04) that sharply cross-cuts cordierite gneiss is treated together with Pyhäntaka fm metavolcanics. Moreover, the geochemistry of the Sopenmäki gabbro (sample JP-157) is shown together with group Pyhäntaka SW.

The metavolcanic rocks are mainly medium-K basalts and basaltic andesites (Figs. 7a, 7b and 7c).

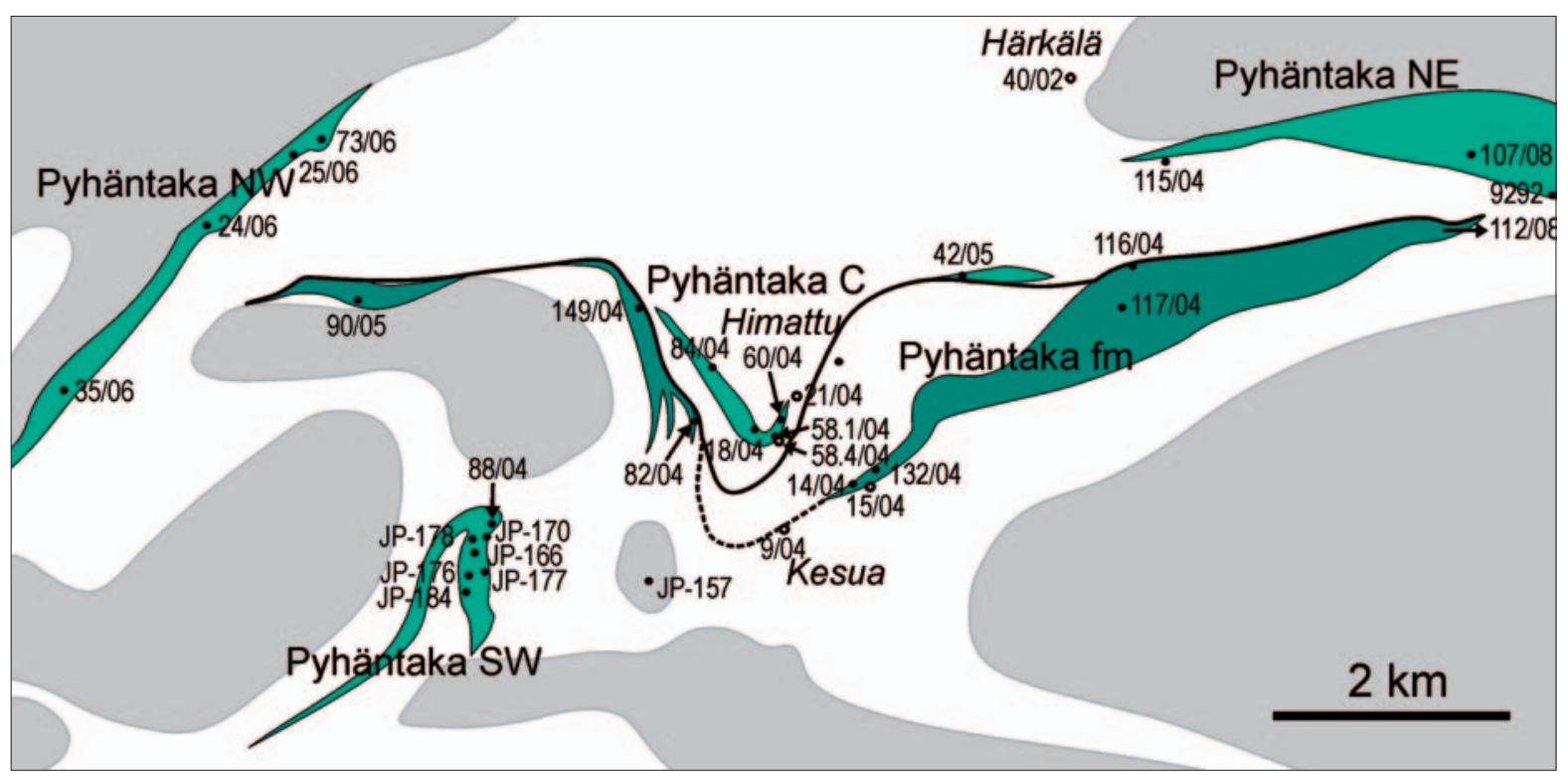

Fig. 6. Sample sites in the Pyhäntaka area. Metavolcanic rock areas are grouped according to their location (see also Fig. 1). Filled circles $=$ metavolcanic rock, open circle $=$ metasedimentary rock. 
The rocks in Pyhäntaka SW are mainly basaltic whereas the rocks to the north of the Pyhäntaka formation range from basalt to andesite; a sample from a rather felsic rock in Pyhäntaka NW (sample 25.2/06, Table 1) plots close to the andesite-dacite boundary. A felsic clast analysed from the volcaniclastic rock (sample 60.2/04) shows affinity to dacite based on high $\mathrm{SiO}_{2}$.

In the MORB-normalized spidergrams (multielement diagrams), the metavolcanic rocks of the
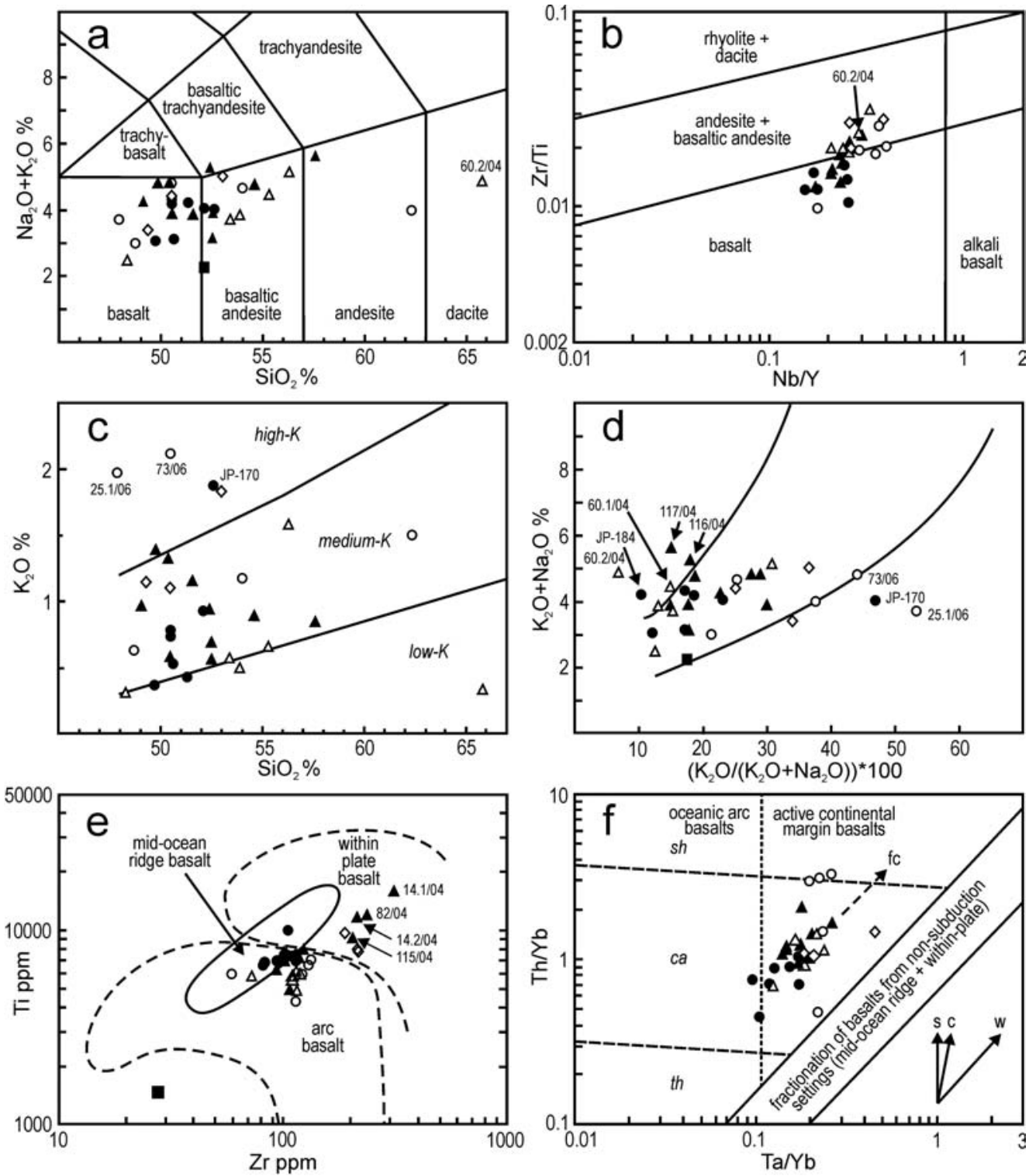

- Pyhäntaka NW

$\triangle$ Pyhäntaka C

$\diamond$ Pyhäntaka NE

\. Pyhäntaka fm

- Sopenmäki gabbro

Fig. 7. Various diagrams on the Pyhäntaka metavolcanic rocks. (a) Total alkali vs. silica (TAS) diagram (after LeBas et al., 1986). (b) Zr/Ti vs. Nb/Y (after Pearce, 1996). (c) $\mathrm{K}_{2} \mathrm{O}$ vs. SiO $\mathrm{S}_{2}$ (fields from Peccerillo \& Taylor, 1976). (d) Alkali alteration diagram (after Hughes, 1973), e) Ti vs. Zr (basalt fields from Pearce et al., 1981). f) Th/Yb vs.Ta/Yb (after Pearce, 1983). th $=$ tholeiitic, $\mathrm{ca}=$ calc-alkaline, $\mathrm{sh}=$ shoshonitic, $\mathrm{s}=$ subduction zone enrichment, $\mathrm{c}=$ crustal contamination, $\mathrm{w}=$ within plate enrichment, $\mathrm{fc}=$ fractional crystallization. 
Table 1. Chemical compositions of the metavolcanic and dike rocks in the Pyhäntaka area. See Fig. 6 for sample sites.

\begin{tabular}{|c|c|c|c|c|c|c|c|c|c|c|c|c|c|c|c|c|}
\hline \multirow{2}{*}{$\begin{array}{l}\text { Group } \\
\text { Sample }\end{array}$} & \multicolumn{5}{|c|}{ Pyhäntaka NW } & \multicolumn{6}{|c|}{ Pyhäntaka C } & \multicolumn{3}{|c|}{ Pyhäntaka NE } & \multicolumn{2}{|c|}{ Pyhäntaka fm } \\
\hline & $24 / 06$ & $25.1 / 06$ & $25.2 / 06$ & $35 / 06$ & $73 / 06$ & $18 / 04$ & $58.1 / 04$ & $60.1 / 04$ & $60.2 / 04$ & $84 / 04$ & $42 / 05$ & 107/08 & 112/08 & 9292 & $14.1 / 04$ & $14.2 / 04$ \\
\hline \multicolumn{17}{|l|}{ (wt-\%) } \\
\hline$x$ & 6776166 & 6776760 & 6776863 & 6774760 & 6776894 & 6774350 & 6774358 & 6774600 & 6774600 & 6774971 & 6775742 & 6776766 & 6776120 & 6776430 & 6773960 & 6773960 \\
\hline y & 3432688 & 3433425 & 3433470 & 3431485 & 3433668 & 3437375 & 3437538 & 3437590 & 3437590 & 3436980 & 3439102 & 3443414 & 3446462 & 3444100 & 3438186 & 3438186 \\
\hline $\mathrm{SiO}_{2}$ & 54.0 & 47.9 & 62.3 & 48.7 & 50.5 & 53.4 & 53.9 & 55.3 & 65.8 & 56.3 & 48.3 & 50.5 & 49.3 & 53.0 & 49.1 & 50.5 \\
\hline $\mathrm{TiO}_{2}$ & 1.00 & 1.19 & 0.73 & 1.00 & 1.11 & 0.98 & 1.00 & 1.03 & 0.81 & 0.94 & 0.97 & 1.35 & 1.59 & 1.29 & 2.66 & 1.96 \\
\hline $\mathrm{Al}_{2} \mathrm{O}_{3}$ & 17.4 & 14.2 & 16.5 & 15.7 & 16.7 & 16.7 & 16.7 & 17.1 & 17.3 & 16.8 & 15.5 & 17.3 & 20.3 & 17.3 & 16.2 & 16.6 \\
\hline $\mathrm{FeO}^{\text {tot }}$ & 8.96 & 13.3 & 6.39 & 10.3 & 11.2 & 7.71 & 8.84 & 8.36 & 3.44 & 7.41 & 9.45 & 8.36 & 9.90 & 7.47 & 12.0 & 10.1 \\
\hline $\mathrm{MnO}$ & 0.15 & 0.23 & 0.11 & 0.16 & 0.18 & 0.15 & 0.13 & 0.15 & 0.07 & 0.11 & 0.16 & 0.13 & 0.14 & 0.16 & 0.17 & 0.16 \\
\hline MgO & 3.43 & 7.05 & 3.66 & 7.09 & 4.89 & 5.10 & 4.85 & 3.96 & 1.08 & 4.90 & 9.52 & 5.05 & 4.61 & 3.46 & 4.10 & 4.34 \\
\hline $\mathrm{CaO}$ & 7.70 & 7.47 & 4.93 & 10.9 & 6.82 & 9.76 & 8.14 & 8.04 & 5.67 & 6.43 & 11.1 & 9.13 & 8.36 & 6.11 & 9.10 & 10.2 \\
\hline $\mathrm{Na}_{2} \mathrm{O}$ & 3.49 & 1.74 & 2.51 & 2.36 & 2.72 & 3.15 & 3.36 & 3.80 & 4.55 & 3.57 & 2.18 & 3.30 & 2.25 & 3.19 & 3.29 & 3.31 \\
\hline $\mathrm{K}_{2} \mathrm{O}$ & 1.18 & 1.98 & 1.51 & 0.64 & 2.12 & 0.57 & 0.50 & 0.66 & 0.33 & 1.58 & 0.31 & 1.10 & 1.15 & 1.83 & 0.96 & 0.58 \\
\hline $\mathrm{P}_{2} \mathrm{O}_{5}$ & 0.31 & 0.34 & 0.14 & 0.15 & 0.35 & 0.24 & 0.19 & 0.21 & 0.19 & 0.21 & 0.18 & 0.38 & 0.41 & 0.64 & 0.68 & 0.46 \\
\hline Total & 97.6 & 95.4 & 98.8 & 96.9 & 96.6 & 97.8 & 97.6 & 98.6 & 99.2 & 98.3 & 97.7 & 96.6 & 98.0 & 94.5 & 98.2 & 98.2 \\
\hline $\begin{array}{l}\text { Mg \# } \\
(p p m)\end{array}$ & 34.6 & 42.3 & 44.2 & 48.9 & 37.6 & 47.8 & 43.2 & 39.6 & 30.3 & 47.8 & 58.2 & 45.5 & 39.2 & 39.1 & 32.1 & 37.4 \\
\hline $\mathrm{Ba}$ & 486 & 473 & 384 & 181 & 572 & 186 & 229 & 201 & 188 & 255 & 129 & 147 & 149 & 252 & 192 & 122 \\
\hline $\mathrm{Rb}$ & 49 & 229 & 86 & 14 & 141 & 13 & 14 & 20 & 12 & 40 & 12 & 59 & 85 & 163 & 31 & 13 \\
\hline $\mathrm{Sr}$ & 496 & 287 & 524 & 366 & 433 & 509 & 387 & 522 & 645 & 410 & 478 & 374 & 435 & 427 & 374 & 412 \\
\hline $\mathrm{Zr}$ & 112 & 119 & 103 & 59.3 & 122 & 108 & 123 & 126 & 121 & 115 & 65.3 & 213 & 196 & 205 & 296 & 227 \\
\hline $\mathrm{Nb}$ & 7.78 & 8.58 & 4.12 & 3.02 & 7.55 & 5.22 & 5.04 & 5.37 & 4.59 & 4.50 & 3.15 & 7.27 & 9.62 & 13.8 & 13.7 & 10.8 \\
\hline$Y$ & 21 & 26 & 10 & 19 & 22 & 16 & 21 & 17 & 14 & 20 & 14 & 35 & 44 & 33 & 55 & 42 \\
\hline $\mathrm{Hf}$ & 3.19 & 3.13 & 2.89 & 1.89 & 3.64 & 2.75 & 3.14 & 3.13 & 2.95 & 3.20 & 1.70 & 4.83 & 4.52 & 4.74 & 7.22 & 5.47 \\
\hline Ta & 0.44 & 0.64 & 0.29 & 0.38 & 0.50 & 0.31 & 0.28 & 0.38 & 0.29 & 0.42 & b.d. & 0.53 & 0.69 & 1.38 & 0.84 & 0.74 \\
\hline Th & 6.20 & 8.18 & 1.83 & 0.83 & 7.56 & 2.43 & 1.53 & 1.86 & 1.90 & 1.97 & 1.25 & 3.10 & 3.44 & 4.45 & 4.52 & 4.05 \\
\hline U & 2.46 & 4.10 & 1.31 & 0.73 & 3.50 & 1.68 & 0.96 & 1.07 & 0.87 & 1.18 & 0.25 & 2.34 & 1.94 & 6.24 & 2.53 & 2.30 \\
\hline S & 111 & 78 & 2357 & 447 & 60 & b.d. & 97 & b.d. & 278 & b.d. & b.d. & 169 & 480 & 591 & 70 & b.d. \\
\hline V & 219 & 320 & 153 & 306 & 276 & 192 & b.d. & b.d. & b.d. & b.d. & 224 & 249 & 243 & 184 & 334 & 288 \\
\hline $\mathrm{Cu}$ & b.d. & 25 & 33 & 75 & 102 & 41 & 56 & 32 & 62 & 24 & 126 & 164 & 117 & 169 & 183 & 88 \\
\hline $\mathrm{Zn}$ & 120 & 166 & 110 & 102 & 129 & 91 & 102 & 99 & 69 & 91 & 96 & 109 & 118 & 119 & 163 & 129 \\
\hline $\mathrm{Cr}$ & 34 & 60 & 79 & 162 & 33 & 106 & 73 & b.d. & b.d. & 86 & 361 & 149 & 127 & 48 & b.d. & 56 \\
\hline $\mathrm{Ni}$ & b.d. & 48 & 38 & 77 & 32 & 66 & 61 & 21 & b.d. & 61 & 189 & 48 & 69 & 29 & 39 & 72 \\
\hline La & 18.3 & 17.1 & 9.57 & 6.21 & 17.7 & 14.1 & 10.4 & 11.3 & 16.5 & 13.6 & 9.26 & 19.3 & 21.5 & 28.1 & 28.4 & 22.9 \\
\hline $\mathrm{Ce}$ & 40.2 & 38.9 & 20.6 & 15.0 & 40.1 & 32.9 & 25.6 & 27.4 & 28.6 & 28.8 & 20.4 & 43.5 & 50.1 & 62.2 & 67.0 & 54.2 \\
\hline $\operatorname{Pr}$ & 5.04 & 5.29 & 2.56 & 2.04 & 5.39 & 4.45 & 3.38 & 3.60 & 3.12 & 3.88 & 2.81 & 5.70 & 6.51 & 8.32 & 8.95 & 7.26 \\
\hline $\mathrm{Nd}$ & 23.6 & 23.8 & 10.7 & 10.3 & 24.1 & 19.6 & 14.9 & 16.4 & 12.3 & 16.4 & 13.7 & 25.4 & 28.8 & 32.7 & 41.0 & 33.2 \\
\hline Sm & 4.98 & 5.15 & 2.46 & 2.73 & 5.65 & 4.14 & 3.68 & 3.54 & 2.70 & 3.41 & 3.07 & 5.64 & 6.72 & 7.20 & 9.68 & 7.69 \\
\hline Eu & 1.38 & 1.37 & 0.83 & 0.96 & 1.43 & 1.29 & 1.13 & 1.28 & 0.85 & 1.15 & 1.03 & 1.46 & 1.83 & 1.80 & 2.24 & 2.06 \\
\hline Gd & 5.24 & 5.91 & 2.78 & 3.36 & 5.90 & 4.48 & 4.44 & 4.04 & 3.06 & 4.14 & 3.55 & 6.11 & 8.00 & 7.12 & 10.90 & 9.33 \\
\hline $\mathrm{Tb}$ & 0.74 & 0.86 & 0.40 & 0.52 & 0.89 & 0.60 & 0.64 & 0.62 & 0.44 & 0.53 & 0.52 & 0.92 & 1.09 & 1.05 & 1.74 & 1.38 \\
\hline Dy & 3.74 & 5.01 & 2.19 & 3.04 & 4.58 & 3.19 & 3.89 & 3.57 & 2.43 & 2.93 & 3.06 & 5.30 & 6.60 & 6.05 & 9.29 & 7.84 \\
\hline Ho & 0.77 & 0.93 & 0.41 & 0.67 & 1.04 & 0.70 & 0.82 & 0.77 & 0.56 & 0.62 & 0.65 & 1.05 & 1.29 & 1.11 & 1.85 & 1.65 \\
\hline $\mathrm{Er}$ & 2.06 & 2.75 & 1.30 & 1.82 & 2.78 & 1.83 & 2.41 & 2.32 & 1.57 & 1.51 & 1.78 & 2.84 & 3.50 & 3.18 & 5.50 & 4.49 \\
\hline $\mathrm{Tm}$ & 0.30 & 0.40 & 0.19 & 0.25 & 0.37 & 0.27 & 0.37 & 0.32 & 0.22 & 0.25 & 0.25 & 0.41 & 0.49 & 0.50 & 0.73 & 0.65 \\
\hline $\mathrm{Yb}$ & 1.98 & 2.47 & 1.24 & 1.73 & 2.54 & 1.87 & 2.24 & 2.05 & 1.34 & 1.76 & 1.72 & 2.87 & 3.30 & 3.04 & 4.85 & 4.02 \\
\hline Lu & 0.30 & 0.42 & 0.18 & 0.28 & 0.41 & 0.30 & 0.33 & 0.32 & 0.21 & 0.25 & 0.23 & 0.40 & 0.50 & 0.48 & 0.79 & 0.63 \\
\hline
\end{tabular}

b.d. = below detection limit. Magnesium number is given as atomic fraction: $\mathrm{Mg} \#=100\left[\mathrm{Mg}^{2+} /\left(\mathrm{Mg}^{2+}+\mathrm{Fe}^{2+}\right)\right] ;\left(\mathrm{Fe}^{2+}+\mathrm{Fe}^{3+}\right)$ counted as $\mathrm{Fe}^{2+}$. 


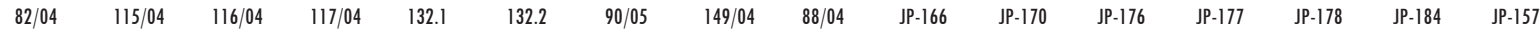

dike $\quad / 04 \quad$ sill sill? sill

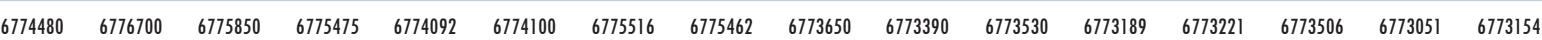

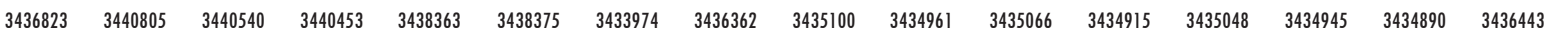

\begin{tabular}{|c|c|c|}
\hline 49.8 & 51.6 & \\
\hline
\end{tabular}

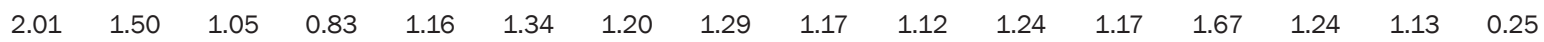

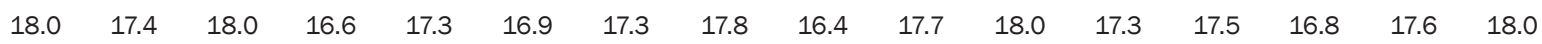

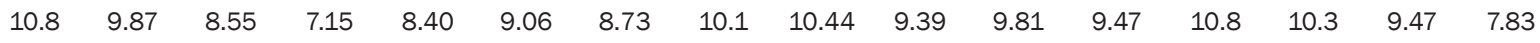

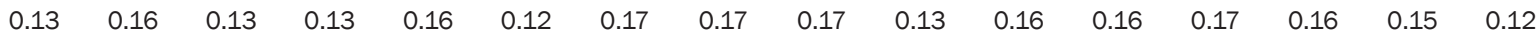

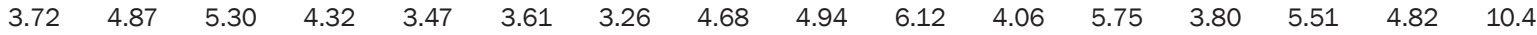

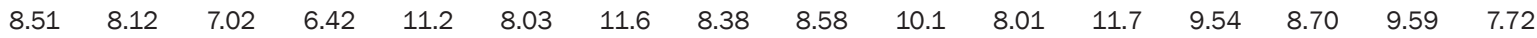

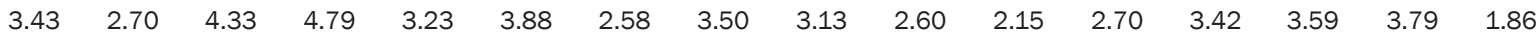

$\begin{array}{llllllllllllllll}1.39 & 1.16 & 0.94 & 0.84 & 0.69 & 0.89 & 0.56 & 1.32 & 0.93 & 0.53 & 1.88 & 0.37 & 0.78 & 0.74 & 0.43 & 0.39\end{array}$

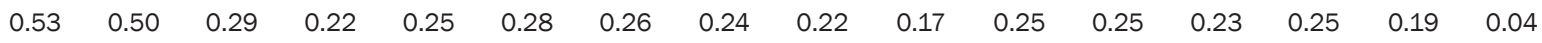

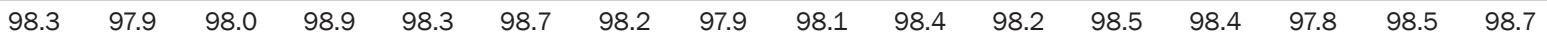

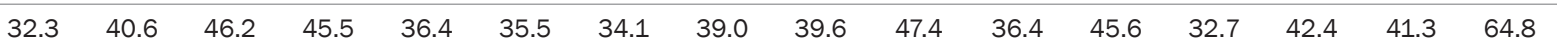

\begin{tabular}{|c|c|c|c|c|c|c|c|c|c|c|c|c|c|c|c|}
\hline 358 & 276 & 134 & 199 & 215 & 197 & 186 & 309 & 228 & 144 & 290 & 194 & 163 & 172 & 161 & 129 \\
\hline 54 & 41 & 36 & 19 & 21 & 31 & 13 & 54 & 42 & 17 & 129 & 10 & 16 & 20 & & 17 \\
\hline 484 & 533 & 579 & 552 & 387 & 393 & 429 & 314 & 337 & 396 & 310 & 487 & 281 & 416 & 506 & 447 \\
\hline 268 & 217 & 98.2 & 114 & 113 & 132 & 112 & 108 & 111 & 79.8 & 106 & 88.5 & 108 & 110 & 91.7 & 22.7 \\
\hline 12.6 & 10.4 & 5.46 & 4.43 & 5.83 & 6.41 & 5.87 & 6.79 & 6.1 & 3.49 & 7 & 4.54 & 7.7 & 4.67 & 4.11 & 1.40 \\
\hline 38 & 30 & 21 & 16 & 23 & 28 & 25 & 26 & 25 & 19 & 27 & 22 & 28 & 25 & 19 & b.d. \\
\hline 7.10 & 5.64 & 2.53 & 2.85 & 3.28 & 3.40 & 3.03 & 2.91 & 2.89 & 2.49 & 2.66 & 2.08 & 3.13 & 2.87 & 2.74 & 0.67 \\
\hline 0.80 & 0.75 & 0.34 & 0.29 & 0.37 & 0.43 & 0.34 & 0.53 & 0.39 & 0.21 & 0.45 & 0.24 & 0.52 & 0.29 & 0.26 & b.d. \\
\hline 5.52 & 4.70 & 3.92 & 2.01 & 2.80 & 3.29 & 2.74 & 2.73 & 2.29 & 1.67 & 2.77 & 1.70 & 2.13 & 1.25 & 1.54 & 1.27 \\
\hline 3.05 & 2.40 & 1.97 & 1.18 & 1.49 & 1.61 & 1.27 & 2.52 & 1.00 & 0.74 & 1.53 & 1.09 & 1.31 & 0.92 & 0.98 & 0.41 \\
\hline 42 & 302 & b.d. & b.d. & b.d. & 85 & 157 & b.d. & b.d. & b.d. & b.d. & b.d. & b.d. & 12 & b.d. & 776 \\
\hline 291 & b.d. & b.d. & b.d. & b.d. & b.d. & 225 & b.d. & 269 & 246 & 284 & 263 & 445 & 259 & 255 & 105 \\
\hline 176 & 121 & 64 & 26 & 74 & 144 & 55 & 31 & 58 & 109 & 77 & 101 & 43 & 157 & 64 & 134 \\
\hline 136 & 134 & 102 & 98 & 98 & 100 & 105 & 113 & 116 & 97 & 141 & 111 & 123 & 129 & 104 & 101 \\
\hline 57 & b.d. & 49 & 106 & 74 & 115 & 69 & 50 & 82 & 84 & 50 & 100 & b.d. & 149 & 66 & 320 \\
\hline 55 & 51 & 40 & 61 & 32 & 48 & 27 & 31 & 35 & 39 & b.d. & 66 & b.d. & 97 & 21 & 178 \\
\hline 29.3 & 24.9 & 24.8 & 13.0 & 14.0 & 16.3 & 13.2 & 10.4 & 11.9 & 9.49 & 13.2 & 14.8 & 14.5 & 14.0 & 11.2 & 5.46 \\
\hline 65.3 & 60.1 & 56.4 & 30.2 & 30.9 & 37.4 & 28.9 & 26.7 & 27.2 & 21.0 & 28.0 & 32.1 & 30.3 & 32.5 & 25.1 & 9.84 \\
\hline 8.78 & 8.18 & 7.03 & 3.66 & 3.98 & 4.57 & 3.80 & 3.45 & 3.60 & 2.84 & 3.81 & 4.37 & 4.07 & 4.45 & 3.40 & 1.09 \\
\hline 41.1 & 36.1 & 31.9 & 15.9 & 18.9 & 20.8 & 16.8 & 17.6 & 17.4 & 14.0 & 18.4 & 19.4 & 19.6 & 20.5 & 16.9 & 4.2 \\
\hline 9.38 & 7.69 & 5.45 & 3.51 & 4.32 & 4.78 & 3.96 & 4.16 & 3.86 & 3.44 & 4.16 & 4.20 & 4.69 & 4.64 & 4.22 & 0.78 \\
\hline 2.48 & 1.82 & 1.69 & 1.14 & 1.37 & 1.34 & 1.21 & 1.29 & 1.16 & 1.11 & 1.32 & 1.17 & 1.34 & 1.44 & 1.40 & 0.49 \\
\hline 10.90 & 8.14 & 5.61 & 3.82 & 5.11 & 5.69 & 4.42 & 5.41 & 4.54 & 4.24 & 5.07 & 4.59 & 5.16 & 5.33 & 4.70 & 0.59 \\
\hline 1.54 & 1.14 & 0.78 & 0.55 & 0.77 & 0.88 & 0.71 & 0.78 & 0.77 & 0.67 & 0.78 & 0.61 & 0.87 & 0.81 & 0.72 & 0.14 \\
\hline 8.89 & 5.97 & 3.49 & 2.74 & 4.52 & 5.03 & 4.36 & 4.75 & 4.37 & 4.16 & 4.57 & 3.53 & 5.09 & 4.85 & 4.38 & 0.79 \\
\hline 1.81 & 1.20 & 0.70 & 0.59 & 0.99 & 1.04 & 0.90 & 1.02 & 0.89 & 0.79 & 0.93 & 0.73 & 1.05 & 0.99 & 0.85 & 0.14 \\
\hline 5.23 & 3.26 & 2.02 & 1.69 & 2.85 & 3.14 & 2.44 & 3.06 & 2.62 & 2.50 & 2.85 & 2.15 & 3.04 & 2.90 & 2.38 & 0.34 \\
\hline 0.67 & 0.47 & 0.28 & 0.25 & 0.39 & 0.44 & 0.35 & 0.46 & 0.37 & 0.36 & 0.41 & 0.27 & 0.45 & 0.41 & 0.36 & b.d. \\
\hline
\end{tabular}


Pyhäntaka area have fairly similar patterns, showing enrichment of the large ion lithophile elements (LILE) $\mathrm{K}, \mathrm{Rb}$, Ba and Th as well as $\mathrm{Ce}$, and relative depletion of Ta and Nb (Fig. 8). At Pyhäntaka fm, three samples of the Korvenniitty metabasalt immediately overlying the meta-arkose (14.1/04, 14.2/ $04,82 / 04)$ as well as the Härkälä mafic dike (115/ $04)$ constitute a separate group with relatively high
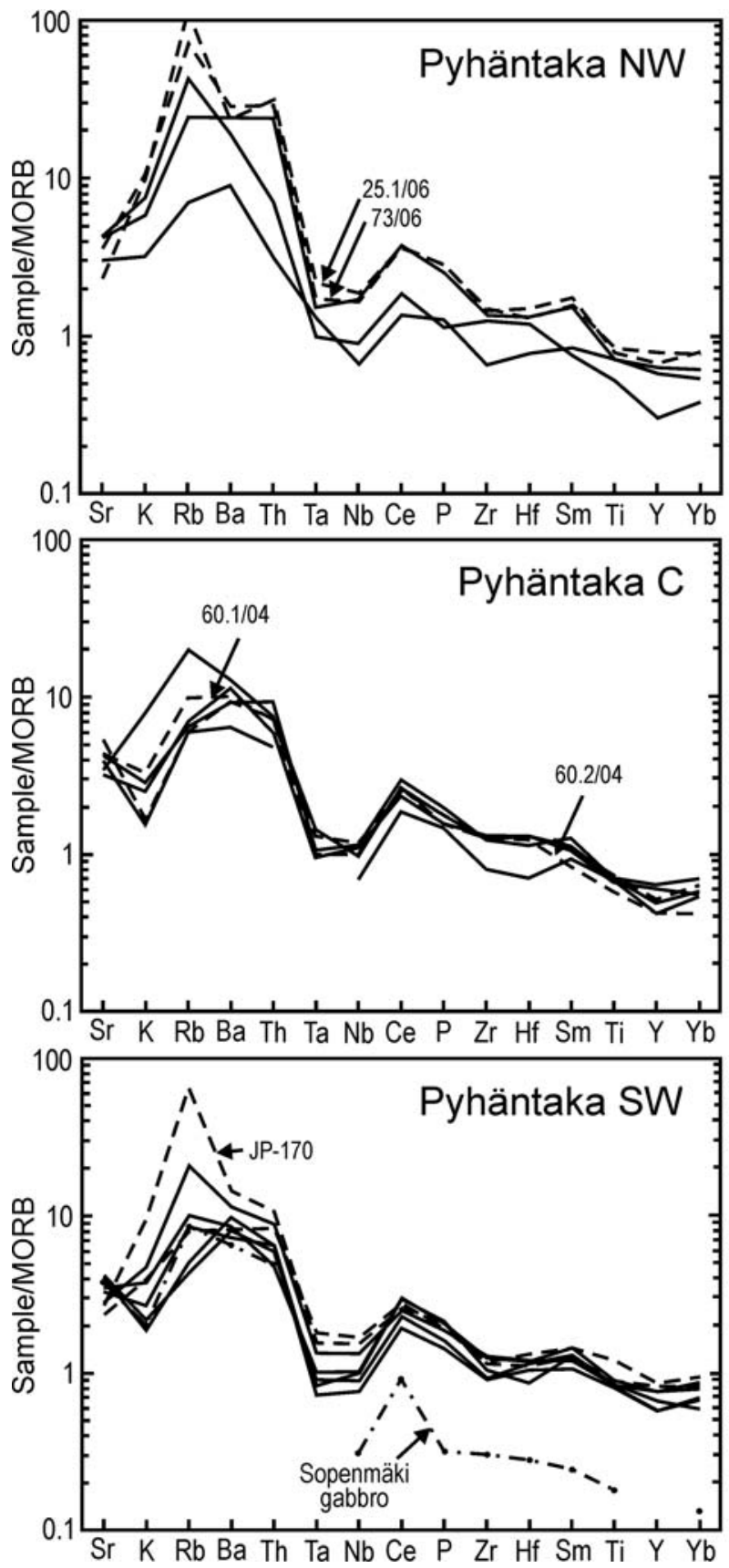

abundances of HFSE; also Pyhäntaka NE samples have higher HFSE. Accordingly, in the rare-earth element (REE) diagram (Fig. 9) these samples have higher REE (especially HREE) abundances than the other Pyhäntaka metavolcanics. In general, the REE patterns are rather flat in the Pyhäntaka metavolcanics, with slight enrichment of LREE over HREE.

In some samples, the sums of major element

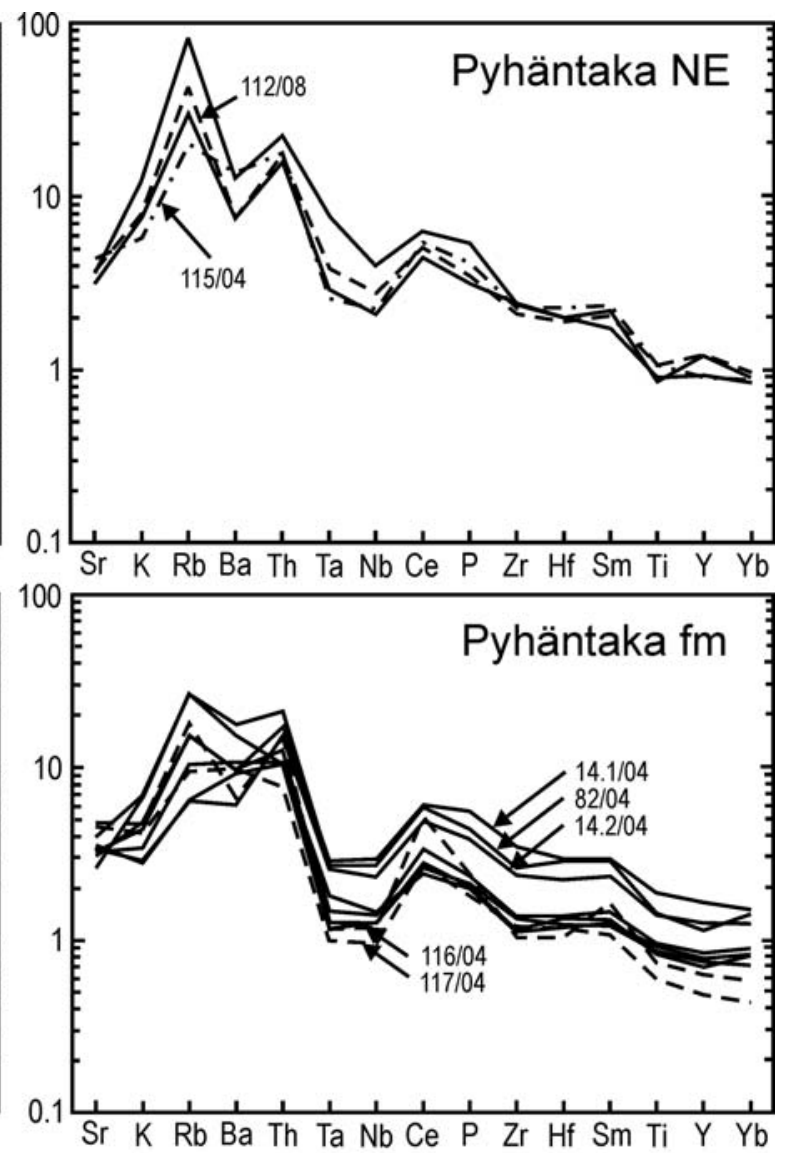

Fig. 8. Mid-ocean ridge basalt (MORB)-normalized multielement diagrams of metavolcanic rocks in the Pyhäntaka area. Normalization after Pearce (1982). Groups and sample sites are as shown in Fig. 6, symbols as in Fig. 7. Broken lines denote samples that plot outside the igneous spectrum in Fig. $7 \mathrm{~d}$. 

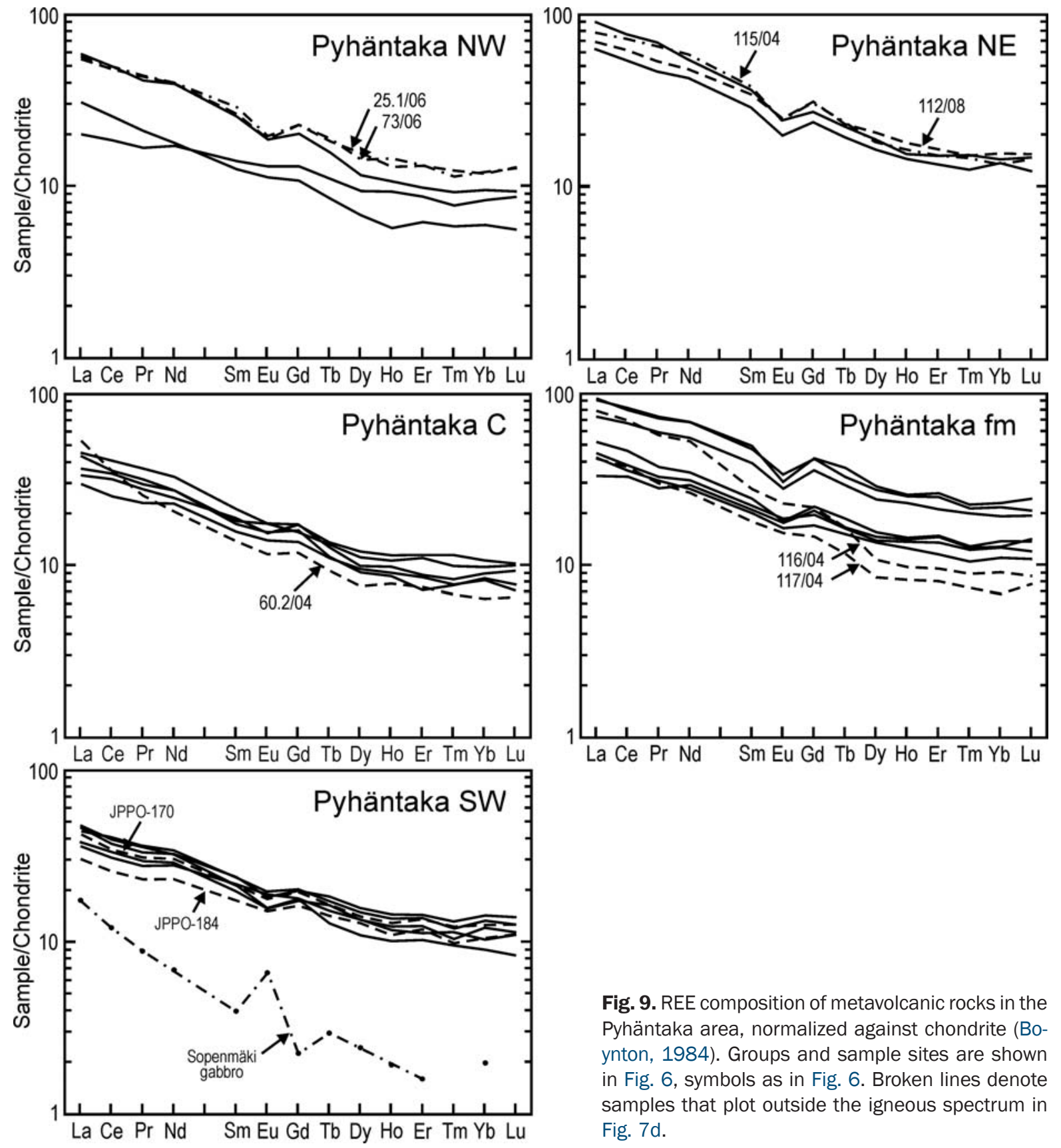

Fig. 9. REE composition of metavolcanic rocks in the Pyhäntaka area, normalized against chondrite (Boynton, 1984). Groups and sample sites are shown in Fig. 6, symbols as in Fig. 6. Broken lines denote samples that plot outside the igneous spectrum in Fig. 7d.

oxides total well under $100 \%$ (95-96 \%; Table 1) making them suspect of alteration. Three samples $(25.1 / 06,73 / 06, \mathrm{JP}-170)$ have relatively high potassium contents and two of them plot well outside the igneous spectrum (Fig 7d). Also their Rb contents are considerably higher than in the Pyhäntaka metavolcanics in general (Table 1), suggesting se- condary alteration or crustal contamination. The sample of dacitic fragment (60.2/04) also plots outside the igneous spectrum; the low $\mathrm{K}$ and elevated $\mathrm{Na}$ content suggest secondary $\mathrm{Na}$ enrichment. The four other samples that plot outside the igneous spectrum $(60.1 / 04,116 / 04,117 / 04$, JP-184) do not have anomalous contents of e.g. Rb. The samples 


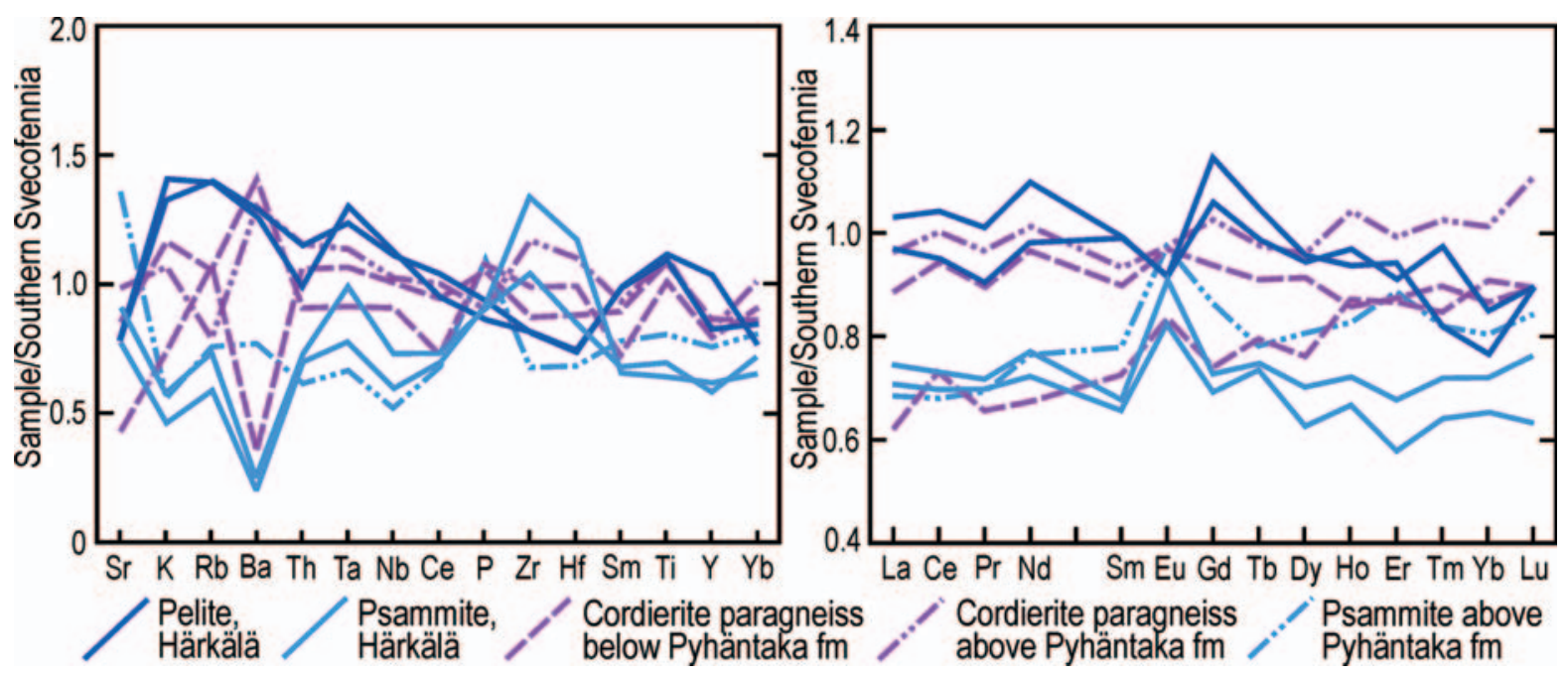

Fig. 10. Major and trace element distribution of metasedimentary rocks in the Pyhäntaka area. The analyses are normalized to the mean of mica schists and mica gneisses of the Southern Svecofennian terrane in Finland (map unit 18 in Rasilainen et al., 2008). (a) Multielement diagram. (b) REE composition. See Fig. 6 for sample sites.

that plot outside the igneous spectrum tend to deviate from the general REE trend in each group.

In the Ti versus $\mathrm{Zr}$ diagram (Fig. 7e), the Pyhäntaka NE samples and part of Korvenniitty metabasalts plot in the within plate basalt field, whereas the other samples plot in the arc basalt / MORB field. In the $\mathrm{Th} / \mathrm{Yb}$ versus $\mathrm{Ta} / \mathrm{Yb}$ diagram (Fig. 7f), the samples mainly plot in the field of calc-alkaline basalts of active continental margins.

The Sopenmäki gabbro has higher $\mathrm{Mg}$ and lower Ti contents than the Pyhäntaka metavolcanics at the same $\mathrm{SiO}_{2}$ levels. Overall, the gabbro has considerably lower HFSE and REE contents than the metavolcanic rocks.

Although not much can be deduced from a single sample, the low element abundances in the spidergram and REE diagrams of the Sopenmäki gabbro as well as the positive Eu anomaly suggest a cumulate origin.

Cordierite paragneisses and psammite were sampled from Himattu and Kesua (below and above the Pyhäntaka formation, respectively; Fig. 6) as well as from Härkälä where the primary pelitic and psammitic layers are well-preserved. The chemical index of alteration (CIA, Nesbitt and Young, 1982) in the cordierite paragneisses and pelitic part of the Härkälä paragneiss is over 60, whereas that of psam- mites is less than 55 (Table 2). When normalized to the mean of mica schists and mica gneisses in southern Finland (Fig. 10), the psammite samples show lower Ba, K, Rb, and REE (except Eu) contents than pelites as well as mica schists and mica gneisses in general. Overall, the metasediments form a rather coherent group: the Himattu and Kesua samples plot between the samples from pelitic and psammitic parts of Härkälä paragneisses.

\section{Discussion}

\subsection{Implications of geochemistry}

The main accretional event in southern Finland ended by 1.87 Ga (e.g. Nironen, 1989; Kilpeläinen, 1998; Pajunen et al., 2008). As the detrital zircon ages of the Muuransuo quartzite are compatible with deposition at or after $1.87 \mathrm{Ga}$, post-collision or within plate type volcanism would be expected. However, only few Pyhäntaka samples plot in the within plate field in Fig. $7 \mathrm{~d}$, and the spidergram patterns with $\mathrm{Ta}-\mathrm{Nb}$ minima and low $\mathrm{Ti} / \mathrm{Y}$ ratios (Fig. 8) as well as plots in the $\mathrm{Th} / \mathrm{Yb}$ versus $\mathrm{Ta} / \mathrm{Yb}$ diagram (Fig. 7f) resemble those of basalts from active continental margins (cf. Pearce, 1983; 1996). According to Pearce (1996), the characteristics of post-collision magmatism vary from volca- 
Table 2. Chemical compositions of cordierite gneisses in the Pyhäntaka area. See Fig. 6 for sample sites.

\begin{tabular}{|c|c|c|c|c|c|c|c|c|}
\hline Group & Härkälä & & & & Kesua & & Himattu & \\
\hline Sample & $\begin{array}{l}40.1 / 02 \\
\text { pelite }\end{array}$ & $\begin{array}{l}40.2 / 02 \\
\text { psammite }\end{array}$ & $\begin{array}{l}40.3 / 02 \\
\text { pelite }\end{array}$ & $\begin{array}{l}40.4 / 02 \\
\text { psammite }\end{array}$ & $\begin{array}{l}\text { 9/04 } \\
\text { cord.gneiss }\end{array}$ & $\begin{array}{l}15 / 04 \\
\text { psammite }\end{array}$ & $\begin{array}{l}21 / 04 \\
\text { cord.gneiss }\end{array}$ & $\begin{array}{l}\text { 58.4/04 } \\
\text { cord.gneiss }\end{array}$ \\
\hline $\mathrm{x}$ & 6777462 & 6777462 & 6777462 & 6777462 & 6773618 & 6773964 & 6774715 & 6774347 \\
\hline y & 3440026 & 3440026 & 3440026 & 3440026 & 3437567 & 3438319 & 3437694 & 3437547 \\
\hline \multicolumn{9}{|l|}{$(w t-\%)$} \\
\hline $\mathrm{SiO}_{2}$ & 60.8 & 77.1 & 60.8 & 73.4 & 65.3 & 69.1 & 65.2 & 62.4 \\
\hline $\mathrm{TiO}_{2}^{2}$ & 0.81 & 0.47 & 0.80 & 0.51 & 0.81 & 0.59 & 0.73 & 0.79 \\
\hline $\mathrm{Al}_{2} \mathrm{O}_{3}^{2}$ & 17.4 & 11.1 & 17.4 & 12.6 & 16.4 & 15.2 & 15.9 & 17.6 \\
\hline $\mathrm{FeO}^{\text {tot }}$ & 7.60 & 3.08 & 7.47 & 3.92 & 6.17 & 3.74 & 6.49 & 7.65 \\
\hline $\mathrm{MnO}$ & 0.08 & 0.02 & 0.08 & 0.03 & 0.07 & 0.07 & 0.09 & 0.05 \\
\hline $\mathrm{MgO}$ & 3.38 & 1.14 & 3.19 & 1.61 & 2.38 & 1.67 & 2.86 & 3.13 \\
\hline $\mathrm{CaO}$ & 1.27 & 1.96 & 1.09 & 2.13 & 2.10 & 3.92 & 1.21 & 2.37 \\
\hline $\mathrm{Na}_{2} \mathrm{O}$ & 1.97 & 2.83 & 1.76 & 3.09 & 2.31 & 3.08 & 1.33 & 1.26 \\
\hline $\mathrm{K}_{2} \mathrm{O}$ & 4.03 & 1.42 & 4.30 & 1.78 & 3.26 & 1.71 & 3.56 & 2.24 \\
\hline $\mathrm{P}_{2}^{2} \mathrm{O}_{5}$ & 0.13 & 0.13 & 0.12 & 0.13 & 0.13 & 0.15 & 0.15 & 0.15 \\
\hline Total & 97.47 & 99.25 & 97.01 & 99.20 & 98.93 & 99.23 & 97.52 & 97.64 \\
\hline CIA & 64.4 & 54.0 & 65.3 & 54.3 & 60.2 & 52.6 & 66.9 & 67.5 \\
\hline \multicolumn{9}{|l|}{$(p p m)$} \\
\hline $\mathrm{Ba}$ & 729 & 117 & 712 & 143 & 736 & 432 & 794 & 200 \\
\hline $\mathrm{Rb}$ & 235 & 99 & 234 & 123 & 133 & 127 & 178 & 180 \\
\hline $\mathrm{Sr}$ & 172 & 170 & 169 & 198 & 213 & 294 & 185 & 92 \\
\hline $\mathrm{Zr}$ & 160 & 261 & 159 & 189 & 220 & 131 & 189 & 172 \\
\hline $\mathrm{Nb}$ & 14.5 & 7.8 & 14.7 & 9.5 & 13.3 & 6.8 & 11.8 & 13.1 \\
\hline Y & 30.0 & 18.0 & 24.0 & 17.0 & 24.0 & 22.0 & 23.0 & 25.0 \\
\hline $\mathrm{Hf}$ & 3.76 & 5.96 & 3.82 & 4.35 & 5.61 & 3.48 & 5.04 & 4.47 \\
\hline $\mathrm{Ta}$ & 1.10 & 0.69 & 1.16 & 0.88 & 1.01 & 0.59 & 0.81 & 0.95 \\
\hline Th & 13.8 & 8.4 & 12.0 & 8.7 & 13.9 & 7.4 & 10.9 & 12.7 \\
\hline $\mathrm{U}$ & 3.05 & 3.27 & 3.74 & 2.51 & 3.78 & 2.16 & 3,16 & 2.99 \\
\hline $\mathrm{V}$ & 144 & 68 & 142 & 72 & 118 & 83 & 134 & b.d. \\
\hline $\mathrm{Cu}$ & 22 & b.d. & b.d. & 27 & b.d. & b.d. & b.d. & 68 \\
\hline $\mathrm{Zn}$ & 137 & 60.0 & 135 & 78.0 & 167 & 69.0 & 124 & 177 \\
\hline $\mathrm{Cr}$ & 109 & 54.0 & 107 & 63.0 & 89.0 & 63.0 & 99.0 & 112 \\
\hline $\mathrm{Ni}$ & 43.0 & b.d. & 58.0 & 24.0 & 39.0 & 24.0 & 42.0 & 59.0 \\
\hline $\mathrm{La}$ & 41.2 & 28.3 & 38.8 & 29.8 & 38.5 & 27.4 & 24.8 & 35.5 \\
\hline $\mathrm{Ce}$ & 83.4 & 55.8 & 76.3 & 58.5 & 80.1 & 54.3 & 58.40 & 75.3 \\
\hline $\operatorname{Pr}$ & 9.61 & 6.62 & 8.59 & 6.83 & 9.18 & 6.58 & 6.24 & 8.52 \\
\hline $\mathrm{Nd}$ & 38.4 & 25.3 & 34.3 & 26.9 & 35.4 & 26.7 & 23.6 & 33.8 \\
\hline $\mathrm{Sm}$ & 6.45 & 4.27 & 6.42 & 4.42 & 6.07 & 5.07 & 4.72 & 5.84 \\
\hline $\mathrm{Eu}$ & 1.10 & 0.99 & 1.10 & 1.09 & 1.17 & 1.17 & 1.00 & 1.16 \\
\hline Gd & 6.87 & 4.16 & 6.36 & 4.37 & 6.15 & 5.19 & 4.45 & 5.62 \\
\hline $\mathrm{Tb}$ & 0.91 & 0.64 & 0.86 & 0.65 & 0.85 & 0.68 & 0.69 & 0.79 \\
\hline Dy & 4.50 & 2.95 & 4.44 & 3.30 & 4.51 & 3.79 & 3.58 & 4.30 \\
\hline Ho & 0.87 & 0.62 & 0.90 & 0.67 & 0.97 & 0.77 & 0.81 & 0.80 \\
\hline $\mathrm{Er}$ & 2.54 & 1.54 & 2.46 & 1.83 & 2.68 & 2.39 & 2.34 & 2.36 \\
\hline $\operatorname{Tm}$ & 0.32 & 0.25 & 0.38 & 0.28 & 0.40 & 0.32 & 0.33 & 0.35 \\
\hline $\mathrm{Yb}$ & 1.99 & 1.70 & 2.21 & 1.87 & 2.63 & 2.09 & 2.36 & 2.25 \\
\hline $\mathrm{Lu}$ & 0.34 & 0.24 & 0.34 & 0.29 & 0.42 & 0.32 & 0.34 & 0.34 \\
\hline
\end{tabular}

b.d. = below detection limit. CIA = Chemical index of alteration (Nesbitt and Young, 1982). 
nic arc (when located above an earlier subduction zone) to within plate (in areas of no previous subduction history). In the case of the Pyhäntaka metavolcanics, the tectonic setting is post-accretion rather than post-collision; the geochemical patterns most probably record inheritance from lithospheric mantle source with a subduction component derived from subduction that preceded accretion of the Southern Svecofennian terrane to the Central Svecofennian terrane.

As volcanic rocks are often subject to alteration processes, Hughes (1973) developed an igneous spectrum to detect secondary metamorphic or metasomatic alteration in these rocks. Since basalts are generally considered to derive from the mantle, rocks relatively rich in $\mathrm{K}$ and $\mathrm{Rb}$ may be suspect of secondary alteration, or crustal contamination. The samples of Pyhäntaka that plot well outside the igneous spectrum (Fig. $7 \mathrm{~d}$ ) are probably altered as can be seen also in their anomalous REE patterns (Fig. 9). However, also some samples that plot inside the spectrum have high contents of $\mathrm{K}$ and especially $\mathrm{Rb}$ (e.g. in Pyhäntaka NE). The negative Ba anomaly seen in samples of Pyhäntaka NW, Pyhäntaka $\mathrm{NE}$ and Pyhäntaka fm may result from crustal contamination of mantle melts or sediment assimilation of mantle melts, in line with reasoning by Lahti- nen (1996, p. 51). Thus it appears that the igneous spectrum does not readily reveal crustal contamination of basalts.

A feature seen in the spidergram and REE patterns of the metavolcanic rocks in Pyhäntaka is that they appear to record differentiation within each group, e.g. in Pyhäntaka SW. In the Th/Yb versus $\mathrm{Ta} / \mathrm{Yb}$ diagram (Fig. 7f), however, the groups exhibit relatively narrow ranges, apart from Pyhäntaka NW that shows high and variable $\mathrm{Th} / \mathrm{Yb}$ values typical of subduction zone enrichment or crustal contamination. Comparison of the most primitive (in terms of $\mathrm{Mg}$-number, $\mathrm{Cr}$ and $\mathrm{Ni}$ ) representatives of each group in Fig. 11 shows notable variation in both spidergram and REE patterns. The spidergram and REE patterns of the paragneiss sample 58.4/ 04, stratigraphically below the Pyhäntaka fm volcanic group, suggest that a contaminant similar to the paragneiss may at least partially explain the variety in the LILE patterns, e.g. Ba minimum as well as increased LREE enrichment in some volcanic rocks. Bearing in mind the bimodal affinity of volcanism in the Pyhäntaka area and the volcaniclastic/epiclastic fragments, the heterogeneity seen in the geochemistry of the volcanic rocks could largely result from assimilation/contamination, although mantle source heterogeneity and secondary
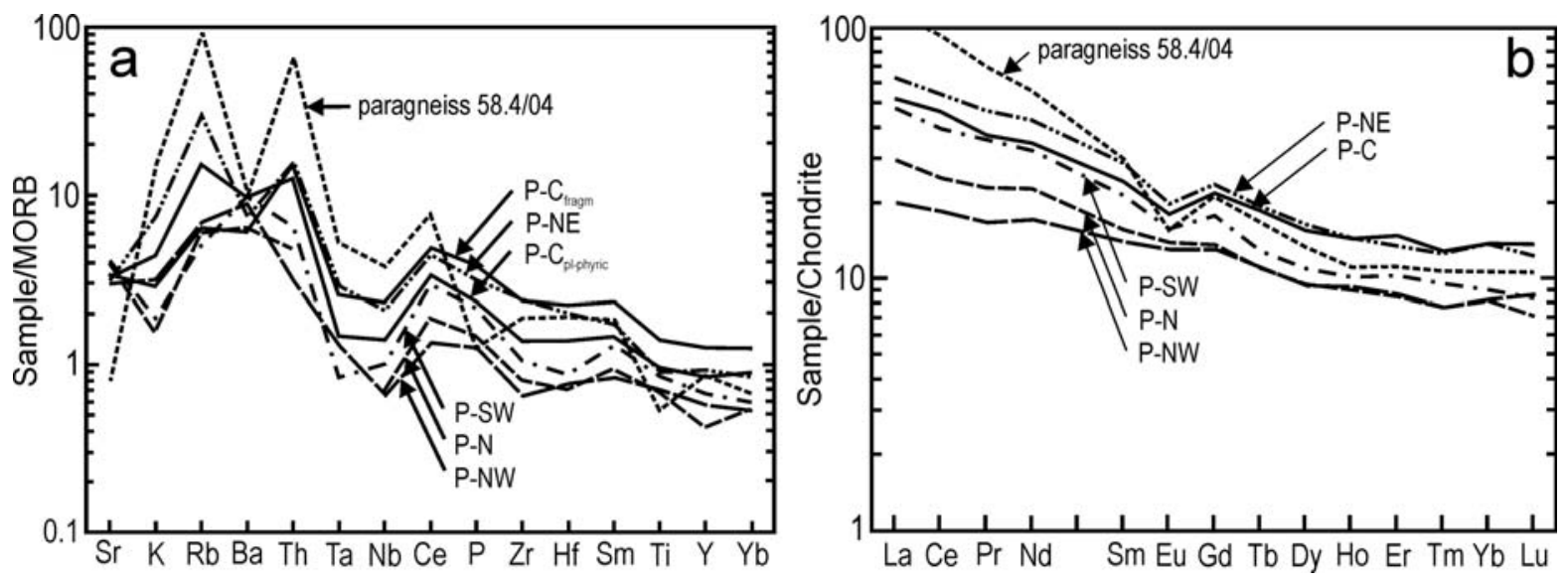

Fig. 11. (a) Mid-ocean ridge basalt (MORB)-normalized multielement diagrams of the most primitive volcanic rock in each of the groups in the Pyhäntaka area, shown in Fig. 6. Normalization after Pearce (1982). P-NW = Pyhäntaka NW (sample 35/06), P-N = Pyhäntaka N (sample 42/05), P-NE = Pyhäntaka NE (sample 107/08), P-C Center, low-Ti variety (sample 132.2/04), P-C fragm $_{\text {I }}$ Pyhäntaka Center, high-Ti variety (14.2/04), P-SW = Pyhäntaka SW (sample JPPO-176). A diagram of paragneiss (58.4/04; Table 2) is added for comparison. (b) REE composition, normalized against chondrite (Boynton, 1984). 
alteration probably have also been involved.

Structural interpretation of the Pyhäntaka area, based on new age determinations (Nironen \& Mänttäri, 2011), indicates that the Härkälä metagraywackes are older $(>1885 \mathrm{Ma})$ than the geochemically rather similar Himattu and Kesua metagraywackes (<1875 Ma); the Härkälä graywackes were deformed and metamorphosed into high-grade gneisses before deposition of the Himattu graywackes. Accordingly, the Pyhäntaka NE metavolcanics may be older than the Pyhäntaka C, Pyhäntaka fm and Pyhäntaka SW metavolcanics. The age difference between the metavolcanics is not certain, however, because the location of the discordance in unknown; the structural setting and age of the Pyhäntaka NW metavolcanics is also unknown. The content of the incompatible elements from $\mathrm{Ta}$ to $\mathrm{Yb}$ is slightly higher in the Pyhäntaka NE samples suggesting a more enriched subcontinental lithospheric mantle source for these samples (cf. Pearce, 1983). Tectonic discrimination diagrams do not give clues to the possible age difference. In the $\mathrm{Ti}$ versus $\mathrm{Zr}$ diagram (Fig. 7e), the Pyhäntaka NE samples and some basalt samples of the Pyhäntaka formation plot in the within plate field and other samples in the arc basalt or MORB field. In the $\mathrm{Th} / \mathrm{Yb}$ versus $\mathrm{Ta} / \mathrm{Yb}$ diagram (Fig. 7f) and Th-Hf-Ta diagram (Wood, 1980, not shown) almost all samples plot in the arc (active continental margin/destructive plate margin) field.

\subsection{Implications for deposition environment}

The variety of rock types in the Pyhäntaka formation, from quartzite (mature sand) through meta-arkose (immature sand) to tuffitic rock and finally basaltic volcaniclastic rock, poses the question of depositional environment. The suggested environment is shown in Fig. 12. The older graywackes (at Himattu) were deposited during exhumation of the accreted crust. The depositional basement consists of newly formed magmatic rocks, possibly also of metamorphosed sedimentary rocks such as the Härkälä paragneisses. The development of quartz-rich sand requires an environment of low topography
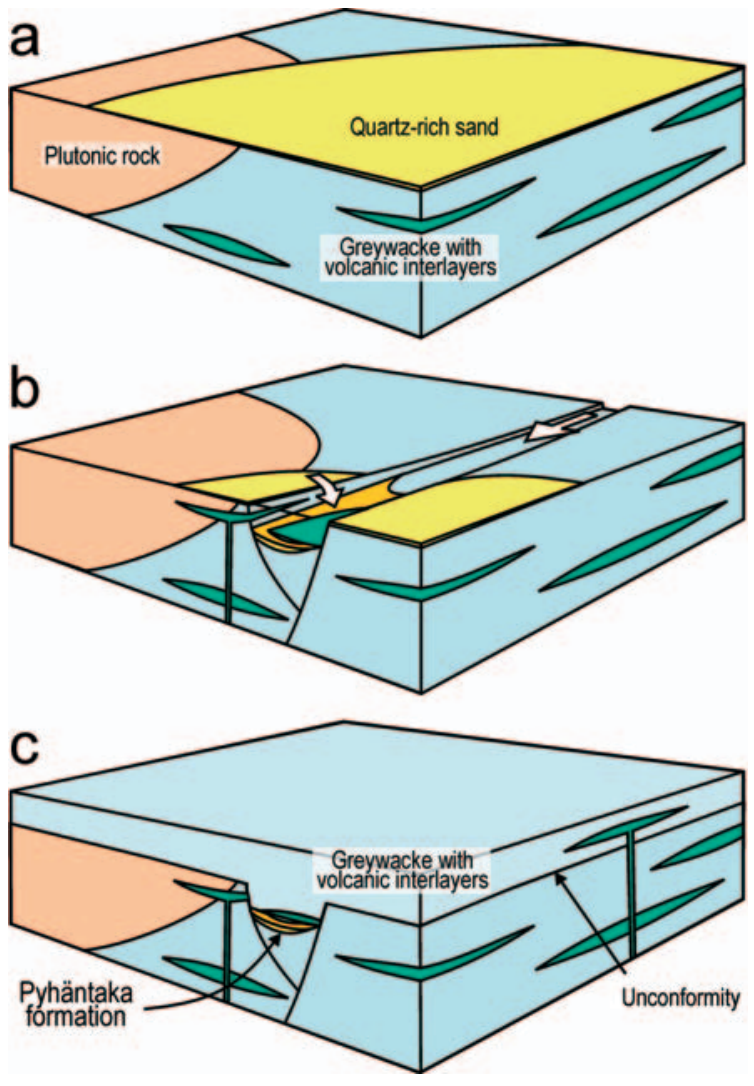

Fig. 12. Schematic presentation of deposition of the Pyhäntaka formation, sketch not in scale. Sediment/rock marking as in Fig. 2. (a) Deposition of quartz-rich sand on top of a weathering crust in rather flat terrain. (b) Development of a narrow rift basin and accumulation of quartzrich sand as well as less mature sediments in the rift during volcanism. (c) Preservation of the down-faulted supracrustal sequence in the rift while surrounding quartzrich sand is recycled among other sediments.

and high degree of weathering. The deposition and maturization of the sand occurred in a stable tectonic setting within the orogenic belt. An unconformity exists between the quartz-rich sand and the weathered crust below (Fig. 12a). Subsequent extension led to basaltic volcanism and opening of a narrow rift (Fig. 12b). Fluvial processes rapidly buried the quartz-rich sand below less-mature material, partly derived from redeposition of the weathered crust. This sand was preserved while the rest of the quartz-rich sand was gradually recycled among other sediments (mainly graywackes; Fig. 12c). The 
angular shape of the dark (duricrust) fragments in the quartzite suggests a short transport distance. These fragments may be clasts from the weathered crust, mixed into the quartz-rich sand during transport in the rift.

\section{Conclusions}

Detailed field work in the Pyhäntaka area allowed to distinguish a volcanic-sedimentary sequence within metagraywackes and psammites. This sequence, named as Pyhäntaka formation, has a maximum thickness of 1000 meters and consists of quartzite at the base, meta-arkose, metatuffite, and metabasalt on top. Judging from previous detrital zircon studies, these rocks were deposited between $1.87 \mathrm{Ga}$ and $1.83 \mathrm{Ga}$, during an intra-orogenic period after accretion and before late collision stage of the Svecofennian orogeny. The proposed model of depositional history consists of graywackes and intercalated mafic-intermediate volcanic rocks that were deposited onto Svecofennian magmatic rocks. A weathering surface, marking at present an unconformity, developed on top of the graywackes and was overlain by mature quartz-rich sand. The other components of the Pyhäntaka formation were deposited in a narrow rift and covered by graywackes.

Because of recycling, the metagraywackes of the Pyhäntaka area are geochemically similar although they represent different tectonic settings. Also the metavolcanic rocks are fairly similar and show mainly arc-type geochemical characteristics although at least the metabasalts of the Pyhäntaka formation were apparently erupted in a postaccretion setting. The Pyhäntaka example shows the difficulty in assessing tectonic setting by elemental geochemistry in the Southern Svecofennian terrane where accretion and post-accretion settings were largely obliterated by late collision.

\section{Acknowledgements}

I am grateful to Yrjö Kähkönen, Markku Väisänen and Arto Luttinen for constructive comments on the manuscript. I also thank Raimo Lahtinen for helping in the interpretation of geochemistry, and Jussi Pokki for his assistance in the field work.

\section{References}

Bergman, S., Högdahl, K., Nironen, M., Ogenhall, E., Sjöström, H., Lundqvist, L. \& Lahtinen, R. 2008. Timing of Palaeoproterozoic intra-orogenic sedimentation in the central Fennoscandian Shield; evidence from detrital zircon in metasandstone. Precambrian Research 161, 231249.

Boynton, W.V. 1984. Geochemistry of the rare earth elements: meteorite studies. In: Henderson, P. (Ed.), Rare Earth Element Geochemistry. Elsevier, Amsterdam, pp. 63-114.

Eskola, P., Nieminen, E. 1938. The quartzite area of Tiirismaa near Lahti. Bulletin Commission géologique Finlande 123, 29-45.

Hughes, C.J. 1972. Spilites, keratophyres, and the igneous spectrum. Geological Magazine 109, 513-527.

Kähkönen, Y. 1989. Geochemistry and petrology of the metavolcanic rocks of the early Proterozoic Tampere Schist Belt, southern Finland. Geological Survey of Finland, Bulletin 345, 1-104.

Kähkönen, Y. 1999. Stratigraphy of the central parts of the Palaeoproterozoic Tampere Schist Belt, southern Finland: review and revision. Bulletin of the Geological Society of Finland 71, 13-29.

Kilpeläinen, T. 1998. Evolution and 3D modelling of structural and metamorphic patterns of the Palaeoproterozoic crust in the Tampere-Vammala area, southern Finland. Geological Survey of Finland, Bulletin 397, 1-124.

Korsman, K., Koistinen, T., Kohonen, J., Wennerström, M., Ekdahl, E., Honkamo, M., Idman, H. \& Pekkala, Y. (ed.) 1997. Suomen kallioperäkartta - Berggrundskarta över Finland-Bedrock map of Finland 1:1 000 000. Geological Survey of Finland, Espoo.

Kurhila, M., Vaasjoki, M., Mänttäri, I., Rämö. T. \& Nironen, M. 2005. U-Pb ages and $\mathrm{Nd}$ isotope characteristics of the lateorogenic, migmatizing microcline granites in southwestern Finland. Bulletin of the Geological Society of Finland 77, 105-128.

Lahtinen, R. 1996. Geochemistry of Palaeoproterozoic supracrustal and plutonic rocks in the Tampere-Hämeenlinna area, southern Finland. Geological Survey of Finland, Bulletin 389, 1-113.

Lahtinen, R. \& Nironen, M. 2010. Paleoproterozoic lateritic paleosol-ultra-mature/mature quartzite-meta-arkose successions in southern Fennoscandia - intra-orogenic stage during the Svecofennian orogeny. Precambrian Research 183, 770-790.

Lahtinen, R., Huhma, H. \& Kousa, J. 2002. Contrasting source components of the Paleoproterozoic Svecofennian metasediments: Detrital zircon U-Pb, SM-Nd and geochemical data. Precambrian Research 116, 81-109.

Lahtinen, R., Korja, A. \& Nironen, M. 2005. Paleoproterozoic tectonic evolution. In: Lehtinen, M., Nurmi, P.A. \& Rämö, O.T. (eds.) Precambrian Geology in Finland - Key to the 
Evolution of the Fennoscandian Shield. Developments in Precambrian Geology 14, Elsevier, Amsterdam, pp. 481531.

Lahtinen, R., Huhma, H., Kähkönen, Y. \& Mänttäri, I. 2009. Paleoproterozoic sediment recycling during multiphase orogenic evolution in Fennoscandia, the Tampere and Pirkanmaa belts, Finland. Precambrian Research 174, 310-336.

LeBas, M.J., LeMaitre, R.W., Streckeisen, A. \& Zanettin, B. 1986. A chemical classification of volcanic rocks based on total alkali-silica diagram. Journal of Petrology 27, 745750.

Lehijärvi, M. 1970. Geological map of Finland 1:100 000, PreQuaternary rocks, Sheet 3112 Heinola. Geological Survey of Finland.

Lehijärvi, M. 1979. Pre-Quaternary rocks of the Heinola mapsheet area. Geological map of Finland 1:100 000, Explanation to the maps of Pre-Quaternary rocks, Sheet 3112. Geological Survey of Finland.

Mouri, H., Korsman, K. \& Huhma, H. 1999. Tectonometamorphic evolution and timing of the melting processes in the Svecofennian tonalite-trondhjemite migmatite belt: an example from Luopioinen, Tampere area, southern Finland. Bulletin of the Geological Society of Finland 71, 1-56.

Mouri, H., Väisänen, M., Huhma, H. \& Korsman, K. 2005. $\mathrm{Sm}-\mathrm{Nd}$ garnet and $\mathrm{U}-\mathrm{Pb}$ monazite dating of high-grade metamorphism and crustal melting in the West Uusimaa area, southern Finland. GFF 127, 123-128.

Nesbitt, H.W. \& Young, G.M. 1982. Early Proterozoic climates and plate motions inferred from major element chemistry of lutites. Nature 299, 715-717.

Nironen, M. 1989. Emplacement and structural setting of granitoids in the early Proterozoic Tampere and Savo schist belts, Finland - implications for contrasting crustal evolution. Geological Survey of Finland, Bulletin 346, 183.

Nironen, M., Mänttäri, I. 2011. Timing of accretion, intraorogenic sedimentation and basin inversion in the Paleoproterozoic Svecofennian orogen: the Pyhäntaka area, southern Finland. Precambrian Research, submitted.

Pajunen, M., Airo, M.-L., Elminen, T., Mänttäri, I., Niemelä,
R., Vaarma, M., Wasenius, P. \& Wennerström, M. 2008. Tectonic evolution of the Svecofennian crust in southern Finland. Geological Survey of Finland, Special Paper 47, 15-160.

Pearce, J.A. 1982. Trace element characteristics of lavas from destructive plate margins. In: Thorpe, R.S. (ed.) Andesites. Orogenic andesites and related rocks. Wiley, Chichester, pp. 525-548.

Pearce, J.A. 1983. Role of the sub-continental lithosphere in magma genesis at active continental margins. In: Hawkesworth, C.J. \& Norry, M.J. (eds.) Continental Basalts and Mantle Xenoliths. Shiva, 230-249.

Pearce, J.A. 1996. A User's Guide to Basalt Discrimination Diagrams. In: Wyman, D.A. (ed.) Trace Element Geochemistry of Volcanic Rocks: Applications for Massive Sulphide Exploration. Geological Association of Canada, Short Course Notes 12, 79-113.

Pearce, J.A., Alabaster, T., Shelton, A.W. \& Searle, M.P. 1981. The Oman ophiolite as a Cretaceous arc-basin complex: evidence and implications. Philosophical Transactions of the Royal Society A 300, 299-317.

Peccerillo, R. \& Taylor, S.R. 1976. Geochemistry of Eocene calc-alkaline volcanic rocks from the Kastamonu area, northern Turkey. Contributions to Mineralogy and Petrology 58, 63-81.

Rasilainen, K., Lahtinen, R. \& Bornhorst, T.J. 2007. The Rock Geochemical Database of Finland Manual [Electronic resource]. Geological Survey of Finland, Report of Investigation 164, 1-38.

Rasilainen, K., Lahtinen, R. \& Bornhorst, T.J. 2008. Chemical characteristics of Finnish Bedrock - 1:1 000000 Scale Bedrock Map Units. Geoloogical Survey of Finland, Report of Investigation 171, 1-94.

Väisänen, M., Mänttäri, I. \& Hölttä, P. 2002. Svecofennian magmatic and metamorphic evolution in southwestern Finland as revealed by U-Pb zircon SIMS geochronology. Precambrian Research 116, 111-127.

Wood, D.A. 1980. The application of a Th-Hf-Ta diagram to problems of tectonomagmatic classification and to establishing the nature of crustal contamination of basaltic lavas of the British Tertiary Volcanic Province. Earth and Planetary Science Letters 50, 11-30. 